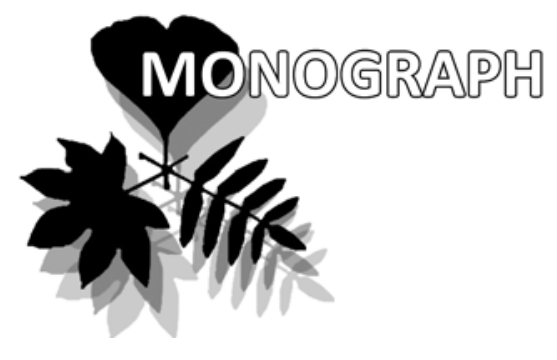

\title{
Survey of the Russian Far East Marchantiales IV: A revision of Ricciaceae (Hepaticae)
}

\author{
Eugene A. Borovichev ${ }^{1,2} * \&$ Vadim A. Bakalin ${ }^{3}$
}

Eugene A. Borovichev ${ }^{1,2, *}$

e-mail: borovichyok@mail.ru

Vadim A. Bakalin ${ }^{3}$

e-mail: vabakalin@gmail.com

${ }^{1}$ Polar-Alpine Botanical Garden-Institute of the Kola Science Center of RAS, Kirovsk, Murmansk Province, 184256, Russia

${ }^{2}$ Institute of Industrial Ecology Problems of the North of the Kola Science Center of RAS, Apatity, Murmansk Province, 184209, Russia

${ }^{3}$ Botanical Garden-Institute FEB RAS, Vladivostok, Russia

* corresponding author

Manuscript received: 20.06 .2016

Review completed: 14.11 .2016

Accepted for publication: 30.11 .2016

Published online: 30.11 .2016

\begin{abstract}
A B S T R A C T
The Russian Far East Ricciaceae comprises two genera: monotypic Ricciocarpos Corda and Riccia L., counting 13 species. The paper provides identification keys, lists of specimens examined, as well as figures and morphological descriptions based on material from area treated. The distribution of the most of taxa within studied area was strongly clarified. Two species are newly recorded for Russia (R. miyakeana Schiffn. and R. nigrella DC.) and two more are new for the Russian Far East (R. beyrichiana Hampe ex Lehm., R. rhenana Lorb. ex Müll. Frib.). K e y w o r d s : Riccia, Ricciocarpos, Ricciaceae, Russia, taxonomy, phytogeography, Hepaticae
\end{abstract}

\section{P E 3 Ю M E}

Боровичев Е.А., Бакамин В.А. Обзор порядка Marchantiales на pocсийском Аальнем Востоке IV: Семейство Ricciaceae (Hepaticae). На российском АаАьнем Востоке семейство Ricciaceae преАстав еено Авумя роАами - монотипным Ricciocarpos Corda и Riccia L. РоА Riccia на изученной территории насчитывает 13 вилов. Приводятся ключи Аля определения виАОв и родов семейства, списки изученных образцов, морфологические описания и оригинальные рисунки. В ходе проведенного исследования значительное количество изученных образцов было переопределено и, таким образом, распространение видов в пределах российского Аальнего Востока существенно уточнено. Ава виАа впервые выявлены во флоре печеночников России (R. miyakeana Schiffn., R. nigrella DC.), и еще Ава ранее не были известны на российском Аальнем Востоке (R. beyrichiana Hampe ex Lehm., R. rhenana Lorb. ex Müll.Frib.).

Кн ю че в ы е ск о в а : Riccia, Ricciocarpos, Ricciaceae, Россия, таксономия, фитогеография, печеночники

\section{N T ROD U C T IO N}

This paper continues the series on taxonomy of Marchantiales in the Russian Far East (Borovichev \& Bakalin 2013, 2014a, b) and Russia (Borovichev et al. 2009, 2012, 2014, 2015) and deals with the largest group of Marchantiales in the Russian Far East. The Ricciaceae counts 14 species in the Russian Far East that are merely common in the southern flank of the area, although sporadically occurring northward to near the Polar Circle. There were no any complete treatments of this family for the eastern part of Russia that makes the present account actual for the promotion of further researches of liverworts in the Far East and adjacent areas.

The representatives of Ricciaceae in the Russian Far East occupy fine soil in man-made (roadsides, vast areas) habitats or areas with naturally disturbed vegetation cover (watercourses banks, etc.) as well as temporarily (rarer constantly) wetted habitats near various pools, ponds and sluggishly flowing rivulets. Northward, however, the Ricciaceae prefers rather un- usual habitats like banks of thermal pools in the areas of recent volcanic activity or fine (mostly clayey) soil in solifluction spots in mountain or zonal tundras.

This study is based on a critical revision of 287 specimens that are kept in the Botanical Garden-Institute, Vladivostok (VBGI, with incorporated collection from VLA) and the herbaria of the Polar-Alpine Botanical Garden-Institute (KPABG), Main Botanical Garden (MHA) and Komarov`s Botanical Institute (LE). Additionally type specimens of Riccia frostii Austin, R. buebeneriana Lindenb., R. nigrella DC. from G and $\mathrm{R}$. nipponica S. Hatt. from NICH were studied. This work was based on not less than $90 \%$ of all existing specimens of Ricciaceae from the Russian Far East preserved in herbaria. As the result of numerous re-identifications and involving the new, previously unpublished material, the distribution of the most of taxa was considerably clarified. The description of morphology and ecology was based on specimens examined if otherwise is not indicated. New records for administrative units are marked by asterisk. 


\section{TAXONOMIC TREATMENT}

Ricciaceae Rchb., Bot. Damen 255. 1828.

Description. Plants thalloid, grow as discrete thalli or complete to incomplete rosettes; terrestrial or aquatic. Thalli small to medium-sized; simple or 1-4-times furcated; ultimate branches linear to obovate; apex truncate to rounded, emarginate; median furrow along midline, present at least at apex; upper surface often concave, reticulate or non reticulate; thallus margin acute to obtuse, slightly to strongly enrolled or plane. Dorsal epidermis 1- or 2-stratose persistent or distinctly lacunose; hyaline, pores lacking or minute to very poorly differentiated; oilcells generally absent. Cilia occasionally present to absent. Air-chambers polyhedral, moderately broad, in 2-3 irregular layers in the middle separated by unistratose walls or in the form of closely juxtaposed vertical lamellae separated by narrow, vertical canals; ventral tissue rather thick to very thin; sometimes with oil-cells. Ventral surface rounded to flat; green to brown or purple tinged; thallus midrib \pm relatively well-defined or poor-defined. Rhizoids long, unicellular, smooth or tuberculate, arising from ventral epidermis. Ventral scales in 1-2 rows, present at least at apex, often early deciduous; small to large, rarely absent, generally imbricate, hyaline or colored - purple, red or black. Vegetative propagation by fragmentation of the rosettes or, sometimes, by apical tubers. Gemmae lacking. Sexual condition usually monoicous, rarer dioicous. Antheridia and archegonia acropetally developed, not aggregated in receptacles; embedded, with only necks exerted, single, distributed along midline or scattered; neck hyaline or purple. Sporophyte without foot and seta; sporophytes projecting domes dorsally or ventrally; capsule with a unistratose wall, lacking cells with thickenings. Spores $40-105 \mu \mathrm{m}$ in diameter; nearly tetrahedral, when mature not aggregated in tetrads; exine complicated; triangular-globular or subglobular, ornamentation mostly reticulate, often species specific. Elaters lacking.

Type: Riccia L., Sp. Pl. 1139. 1753.

The family includes two genera, with the both are known in the Russian Far East: Riccia L. (comprises ca. 240 species worldwide), and monotypic, semicosmopolitan Ricciocarpos Corda.

\section{Key to the genera of the Ricciaceae of the Russian Far East}

1. Thalli with conspicuous linear or linear-lanceolate, dentate ventral scales; dorsal epidermis with distinct pores, surrounded by more than four semicircular cells; epidermis and ventral scales with scattered oil-cells Ricciocarpos Corda

- Thalli with ventral scales vestigial, very small, rarely large and semicrescentic; dorsal epidermis with vestigial or lacking pores, surrounded by four cells; oil-cells lacking ..........

Riccia L.

Ricciocarpos Corda in Opiz (ed.) Beitr. Naturg. 12: 651. 1829.

Type: Ricciocarpos natans (L.) Corda

Monotypic genus, the descriptuion is the same with the sole species.
Ricciocarpos natans (L.) Corda, Naturalientausch 12: 651. 1829. - Riccia natans L. Syst. Nat. (ed. 10) 2: 1339. 1759. Ricciocarpos velutinus (Wilson ex Hook. f.) Steph. Sp. Hepat. 1: 55. 1898. - Riccia velutina Wilson ex Hook. f., Icon. Pl. 3: pl. 249. 1840.

Description (Fig. 1): Plants in mats, partial rosettes or gregarious; aquatic or, rarely, terrestrial (not found in the Russian Far East). Thalli small to medium-sized, 2-6(-8) $\mathrm{mm}$ wide, up to 5-9 $\mathrm{mm}$ long; 2-3-times furcated, shortly to deeply divided; ultimate branches obcuneate to shortly obcordate, narrowed to base; color of upper surface dark-green to yellowish green, sometimes with purple to violet or even brown secondary pigmentation; apex thick, rounded; emarginate; median furrow deep, narrow and dividing near apex, continuing along most of thallus length; upper surface firm, leathery, convex, reticulate; thallus margins thin and very acute; flanks convex and margins acute. Cilia absent. Dorsal epidermis persistent; cells thin-walled; polygonal to hexagonal; $22-36 \times 18-30 \mu \mathrm{m}$; thin walled; pore simple; surrounding $5-6$ thin-walled cells; $35-55 \mu \mathrm{m}$ in diameter. Cross-section 4-8 times wider than thick; furrowed; assimilation tissue occupying most of thallus thickness; air-chambers in 2-3(-5) layers in the middle; each chamber divided by variously directed onelayered laminas; oil-cells scattered; ventral tissue poorly developed, composed by 1-5 layers of cells. Ventral surface flat, violet to brown or rarely greenish; thallus branch midrib 600-960 $\mu \mathrm{m}$ thick in cross-section; \pm poorly defined. Rhizoids absent. Ventral scales in several rows, obliquely oblong to lingulate, not extending beyond apex in terrestrial plants, but linear or linear-lanceolate, dentate, very prominently extending far beyond margin in floating plants; violet or reddish to green or hyaline; up to $6 \mathrm{~mm}$ long; 265-485(-530) wide; cells oblong-hexagonal; margins dentate, with dark red cells. [Monoicous. Antheridia along ridge in central furrow near apex; necks hyaline; up to 100 $\mu \mathrm{m}$. Archegonia immersed, in (1-)2-3(-4) indistinct rows along thallus midline. Spores (42-)60-62(-65) $\mu \mathrm{m}$ in diameter; triangular-globular; almost black; distal surface with poorly defined, 6-8 areolae across the diameter; the entire surface densely covered with granules; proximal surface without areolae; sprinkled with granules and papillae; without distinct trilete scar; wing narrow; wing margin crenulate; elaters lacking (Schljakov 1982, Perold 1999, Damsholt 2002)].

Differentiation. Ricciocarpos natans is well known and one of the most characteristic species of our Marchantiales, that was described in many classic manuals (Müller 1952, Schljakov 1982, Schuster 1992, Paton 1999, Damsholt 2002). It may be easily distinguished from other Russian Ricciaceae species by its short branches, mostly aquatic habitats, prominently linear or linear-lanceolate dentate scales that very extending far beyond margin; firm, leathery, convex, reticulate thallus upper surface; fairly persistent median furrow.

Ecology. This is the most prominent aquatic species of the family, occurring as typical floating plants even more commonly than such species as Riccia rhenana or R. fluitans. It occurs in various pools with stagnant or very sluggishly flowing water, in open areas or along pool sides under canopy 


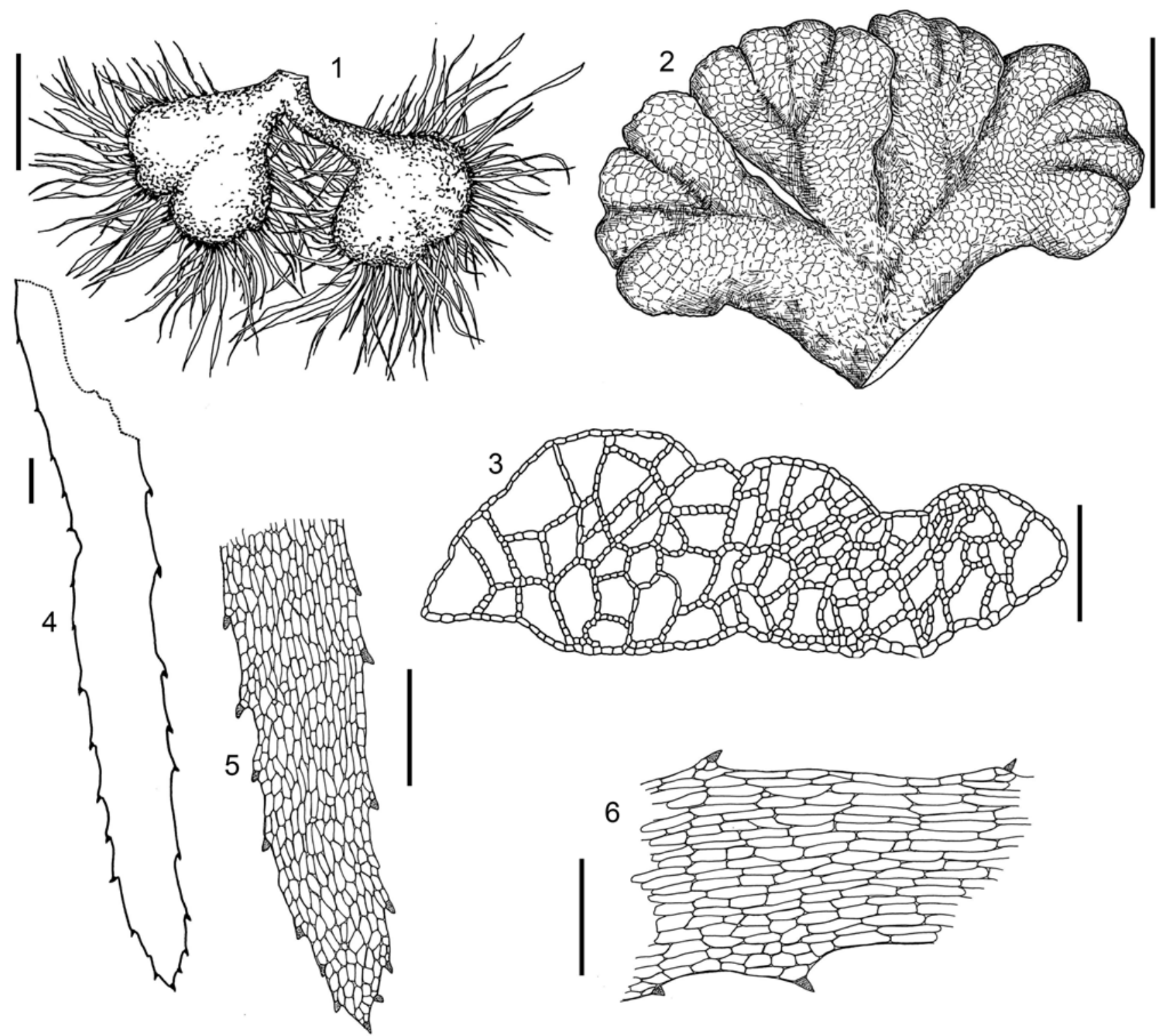

Figure 1 Ricciocarpos natans (L.) Corda: 1, 3-6 - from Primorsky Territory, Borovichev \& Bakalin, \#B\&B 1/9-14 (VBGI); 2 - from Magadan Province, Sinel'nikova, \#155 (VBGI). 1-2 - habit of plant, dorsal view; 3 - thallus transverse section; 4-5 - ventral scales; 6- median part of ventral scale. Scale bars: $5 \mathrm{~mm}$ for $1-2 ; 3 \mathrm{~mm}$ for $2 ; 400 \mu \mathrm{m}$ for $5 ; 300 \mu \mathrm{m}$ for 3-4;200 $\mu \mathrm{m}$ for 6

of semi-submerged Phragmites sp., Miscantus chinensis or Typha sp. If the pool is drained due to various reasons, this species may occur rarely as terrestial plant. Due to atmospheric feeding and strongly unstable water level the frequency and mosaic of the distribution of the species is quite varying. As an example, we had several attempts to find this species in the large pool (where its occurrence was already known) within series of years but found it only twice, with gaps of five years between findings. We may suggest these periodic fluctuations of frequency as the result of variation of snow cover thickness and spring flood intensity.

Distribution. The species is almost cosmopolitan, although lacking in the Arctic and Antarctic (Schuster 1992, Paton 1999, Damsholt 2002). In the area treated it was earlier known from Kamchatka Territory (Arnell 1927), Amur Province (Gambaryan 2000, Bakalin 2010), Sakhalin Province (Horikawa 1935, Kitagawa 1965), Primorsky Territory (Gambaryan 1992, Bakalin 2010). In the course of our studies, the species is recorded for Magadan Province for the first time (Figure 2).

Specimens examined: RUSSIA. Amur Province, Arkharinsk District, Khingan State Nature Reserve, ca. 45 km westward of Arkhara Settlement, sedge fen, floating at water surface, 17.VI.1984, V.V. Yakubov (VBGI; KPABG); * Magadan Province, Ten kinskij District, ca. $7 \mathrm{~km}$ from Elochka Settlement, 2nd terrace of the Kolyma River, Equisetum swampy communities, 1.VIII.2003, N.V. Sinel'nikova \#155 (VBGI; KPABG); Primorsky Territory, Chernigovka District, Vadimovskij State Farm, rice fields, floating at water surface in water channel, 29.VIII.1985, S.K. Gambaryan (VBGI; KPABG); Shkotovo District, near mouth of the Shkotovka River, floating at water surface, 22.IX.1969, P.G. Gorovoj (VBGI; KPABG); ibidem, stream in Tsimukhe (Shkotovka) River valley, floating at water surface in the stream, 15.X.1961, P.G. Gorovoj (VBGI; KPABG); Khanka District, ca. $1 \mathrm{~km}$ northward of Il inka Settlement, shal- 


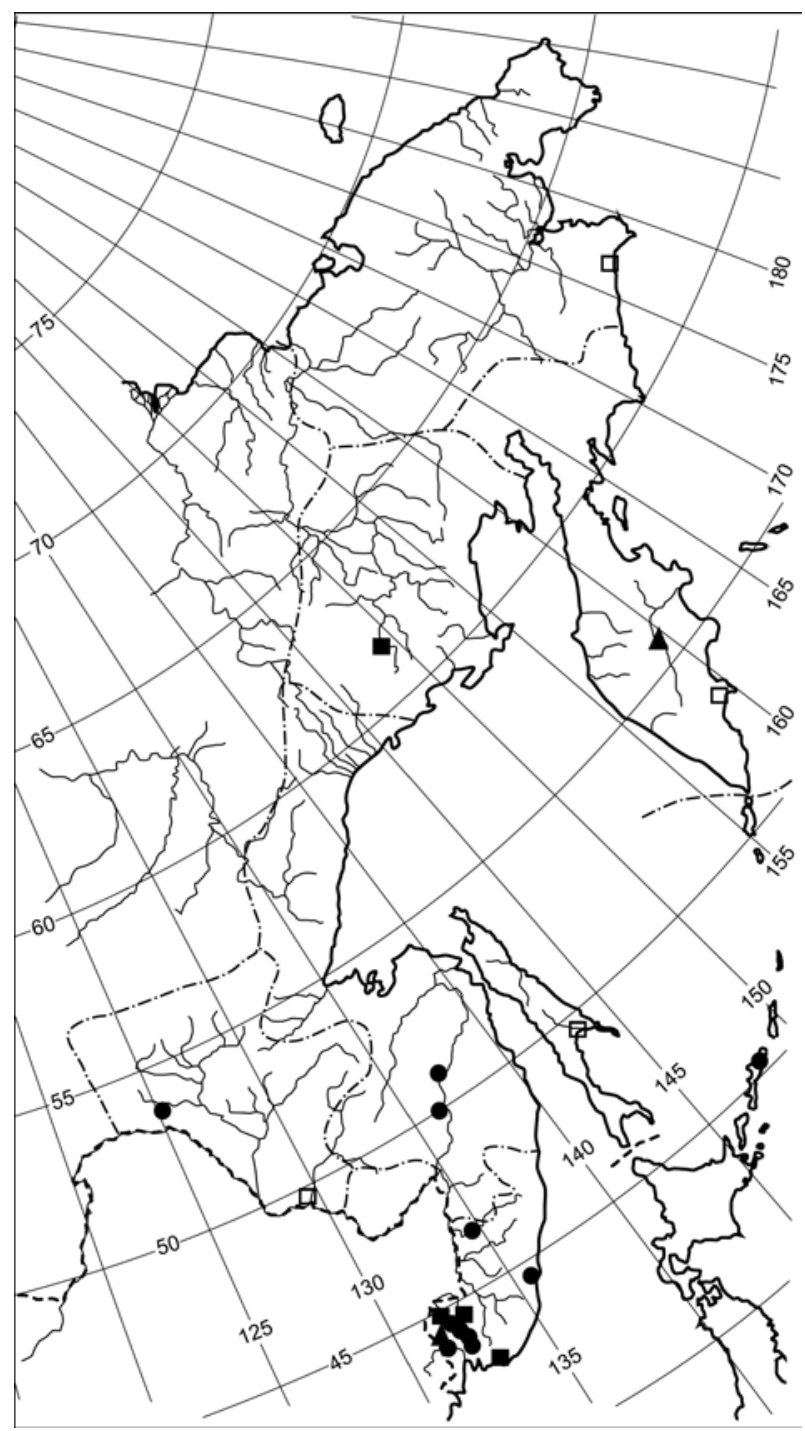

Figure 2 The distribution of Ricciocarpos natans (L.) Corda - squares, Riccia cavernosa Hoffm. - triangles, Riccia fluitans L. - circles. Open figures - literature records, filled figures - studied specimens

low water around old flooded pit among rather dense Calamagrostis, floating at water surface, VIII.2008, V.A. Bakalin \#P75-1-08 (VBGI); ibidem, 8.XI.2014, E.A. Borovichev \& V.A. Bakalin \#BB-1/9-14 (VBGI)).

\section{Riccia L., Sp. Pl. 1139. 1753.}

Description. Plants in thick loosely interwoven patches or as discrete thalli or complete to incomplete rosettes; terrestrial, rarely aquatic. Thalli small to medium-sized, 0.3-5 mm wide, 2-30 $\mathrm{mm}$ long; simple or 1-4 times furcated; ultimate branches linear to lingulate or obcordate to ovate or oblong; color of upper surface light to dark green, sometimes with violet or purplish tint; apex truncate to rounded, emarginate; median furrow deep or shallow, along length of branches or only apical; upper surface often concave; reticulate or non reticulate; thallus margins acute to obtuse; slightly to strongly enrolled or plane; flanks oblique or steep. Dorsal epidermis in 1 or 2 strata, or without a continuous, defined epidermis; persistent or distinctly lacunose, disintegrating with age; hyaline; air pores small, very simple, regular, often poorly differenti- ated; oil-cells lacking. Cilia occasionally present or absent. Aerenchyma compact or loose; air-chambers in two variants: 1) moderately broad, polychedral, empty, never canallike or 2) narrow, erect, closely juxtaposed, divided threadlike lamellae, where each of 4-6 cell rows; ventral tissue rather thick to very thin; sometimes with oil-cells. Ventral surface rounded to flat; green to brown or purple tinged; thallus branch's midrib \pm relatively well- or poor-defined. Rhizoids long, unicellular, smooth or tuberculate, arising from ventral epidermis. Ventral scales in 1-2 rows, present at least in apex, often early destroyed; vestigial to conspicuous, hyaline or colored - then to purple, red or black; usually imbricate, rounded, very rarely triangular. Vegetative propagation by fragmentation of rosettes; sometimes with apical tubers. Sexual condition monoicous, rarely dioicous. Antheridia and archegonia acropetally developed, not aggregated in receptacles; embedded, only necks projecting, single, median along groove or scattered; necks hyaline or purple. Sporophytes projecting domes dorsally or ventrally, released by decay of surrounding tissue; capsule with a unistratose capsule wall, lacking cells with thickenings. Spores 40-105 $\mu \mathrm{m}$ in diameter; nearly tetrahedral, when mature not aggregated in tetrads; ornamentation generally reticulate, areolae small to large, otherwise papillate or vermiculate; proximal face divided into 3 facets by distinct or faint triradiate mark.

Type: R. glauca L., Sp. Pl. 1139. 1753.

The genus counts 13 species in the Russian Far East, classified in two subgenera.

\section{Key to species of Riccia in the Russian Far East}

1. Air-chambers moderately broad, large polyhedral, empty, never open (when epidermis not eroded) and canal-like; dorsal epidermis persistent or distinctly lacunose in older parts; thallus margin smooth (cilia or papillae absent); spores exit through ventral or dorsal side of thallus (subg. Ricciella)

- Air-chambers narrow, erect, closely juxtaposed, divided by unistrasote lamellae; dorsal thallus surface never becoming lacunose and alveolate; cilia or papillae present or absent; spores exit through dorsal side of thallus only (subg. Riccia)

2. Thalli yellow-green, with upper surface often having vinaceous red or purplish to violet secondary pigmentation; thallus width $0.3-1(-1.2) \mathrm{mm}$; terrestrial or aquatic ............. 3

- Thalli light green to yellowish green, upper surface very rarely with slightly purplish secondary pigmentation; thallus width $1.5-3(-5) \mathrm{mm}$; terrestrial

3. Plants growing in thick, loosely interwoven patches or complete to incomplete rosettes with margins green to vinaceous or purplish pigmented in older parts; spore (50-) $55-70(-90) \mu \mathrm{m}$ in diameter; distal face of spore strongly reticulate

- Plants growing in compact, complete rosettes, often with purplish margins and dorsal surface; spores smaller, (42-) $48-52(-55) \mu \mathrm{m}$ in diameter; distal face of spore not reticulate, with irregular short, thin, dispersed lamellae or very rarely finely reticulate.....

Riccia frostii Austin (p. 11)

4. Thallus apex not or rarely slightly furrowed; thallus upper surface not lacunose; plants commonly sterile ....................... 5 - Thalli distinctly furrowed towards apex; at least in older parts 
becoming distinctly lacunose to alveolate; numerous sporangia commonly present

Riccia huebeneriana Lindenb. (p. 13)

5. Thalli merely robust; thallus branchs $0.8-1.2 \mathrm{~mm}$ wide; in cross-section 4-7-times wider than height; air-chambers, to $750 \mu \mathrm{m}$ long and 150-322 $\mu \mathrm{m}$ wide at dorsal view

Riccia rhenana Lorb. ex Müll. Frib. (p. 18)

- Thalli more delicate; thallus branches $0.3-1 \mathrm{~mm}$ wide; in cross-section 3-6-times wider than height; smaller airchambers up to $300 \mu \mathrm{m}$ long and $70-150 \mu \mathrm{m}$ wide at dorsal view ………………………………... Riccia fluitans L. (p. 9)

6. Plants mostly as complete rosettes, rarely as discrete thalli; upper surface slightly to strongly and distinctly lacunose or alveolate at least in older parts [on fine soil along stream courses and man-made habitats like cereal and rice field edges] .

- Plants growing in diffuse patches easily separated into solitary unbranched thalli; thallus upper surface not lacunose even older parts [temporarily dried Carex-Calamagrostis hollows in swampy temperate meadow]

Riccia miyakeana Schiffn. (p. 15)

7. Thallus upper surface green, yellowish green to grayish green; thallus upper surface slightly to strongly and distinctly lacunose throughout; air-chambers (1-)2-3-layered in the middle; spores incompletely alveolate, lamellae without tubercles and spines at the angles

Riccia cavernosa Hoffm. (p. 7)

- Thallus upper surface bluish to grayish-green; air-chambers 1-2-layered in the middle; thallus upper surface persistent or very indistinctly lacunose towards the apex and often less conspicuously lacunose in older parts; spores strongly and completely alveolate, lamellae with tubercles or spines at the angles

Riccia nipponica S. Hatt. (p. 15)

8. Ventral scales distinct, shiny, dark purple to violet-black ...

Riccia nigrella DC. (p. 25)

- Ventral scales white or hyaline to rose or light violet, distinct to virtually absent

9. Ventral scales conspicuous, white, conspicuously projecting apically Riccia lamellosa Raddi (p. 23)

- Ventral scales inconspicuous, never white, generally not projecting

10. Distal face of spores with alveolae lamellae thickened, with a few tubercles at the corners of the alveoli .............. 11 - Distal face of spores with alveolae lamellae thin, with a lot of spinose tubercles at the corners of the alveoli ............... 12

11. Thalli (1.8-)2-3 mm wide; cilia often scarce to numerous near margins; spores larger (75-)90-105 $\mu \mathrm{m}$ in diameter; alveoli wider, 10-16 $\mu \mathrm{m}$ wide ..

Riccia beyrichiana Hampe ex Lehm. (p. 19)

- Thalli (0.8-)1-1.3(-1.8) mm wide; cilia absent; spores smaller (65-)70-80 $\mu \mathrm{m}$ in diameter; alveoli narrower 9-13 $\mu \mathrm{m}$ wide

Riccia bifurca Hoffm. (p. 21)

12. Thallus in cross-section 3-5 times wider than thick; median furrow distinct at apex, but immediately below apex becomes shallow and soon vanishing; distal face of spores slightly spinose-tuberculate ...

Riccia glauca L. (p. 22)

- Thallus in cross-section 2-3 times wider than thick; median furrow distinct at apex and continuing along most of thallus length; distal face of spores distinctly spinose-tuberculate......

Riccia sorocarpa Bisch. (p. 26)

Subgenus Ricciella (A. Braun) Rchb., Deutsch. Bot. Herbarienb. (Nomencl.) 23: 213. 1841. - Ricciella A. Braun, Flo- ra (4)2: 756. 1821. - Riccia sect. Ricciella (A. Braun) Frey et Clark, Univ. Wash. Publ. Biol. 6(1): 31. 1937. - Riccia subgen. Spongodes (Nees) O.H. Volk, Mitt. Bot. Staatssamml. Münch. 19: 456. 1983.

Description. Plants in thick loosely interwoven patches or in complete to incomplete rosettes. Thalli small to medium-sized; often spongy. Dorsal epidermis persistent or very distinctly lacunose towards the apex and in older parts. Assimilation tissue with large, polyhedral empty air-chambers. Ventral scales small to vestigial. Sporangia immersed, or bulging ventrally or dorsally. Spores mediumsized to large; tetrads separating at maturity; alveolate at least at the distal face; proximal face flat, sharply delaminated, with a distinct wing margin; not permanently united in tetrads.

Type: Riccia fluitans L., Sp. Pl. 1139. 1753.

A subgenus includes more than 30 species (Söderström et al. 2016), five of them are known in the Russian Far East.

Riccia cavernosa Hoffm., Deutschl. Fl. 2: 95. 1795. emend Raddi, Opusc. Sci. (Bologna) 2: 351-353. 1818.

Description (Fig. 3: 1-4): Plants often in complete rosettes or as discrete thalli. Thalli medium-sized, 1.5-2(-2.7) $\mathrm{mm}$ wide, 4-7(-8) mm long; repeatedly dichotomously furcate; ultimate branches shortly to deeply divided, subparallel or crowded and overlapping; obcuneate or obovate to oblong; color of upper surface light green to yellowish green, rarely with purplish secondary pigmentation; upper surface slightly to strongly distinctly lacunose or alveolate, air-chambers gradually coalesce generally in older parts of thallus; apex rounded, shortly emarginate; median furrow distinct at apex, shallow; thallus margins not incurved; thick; rounded in cross section, obtuse. Dorsal epidermis cells polygonal, shiny, $60-75(-80) \times(46) 50-55 \mu \mathrm{m}$, thin to thick-walled; often collapsed in the herbarium. Crosssection not furrowed (plane-convex to slightly biconvex); 1.5-2.5(-4) times wider than thick; assimilation tissue high, spongy; up to $600-800 \mu \mathrm{m}$ thick; $3 / 4-4 / 5$ the thallus thickness in the middle; air-chambers large, polygonal; in (1-)2-3(-4) layers in the middle; ventral tissue parenchymatous, consisting of thin-walled cells; $1 / 5-1 / 4$ the thallus thickness in the middle. Ventral surface flat or weakly convex, green; thallus branches midrib fleshy, 650-950 $\mu \mathrm{m}$ thick in cross-section; \pm relatively well-defined. Rhizoids smooth and pegged, hyaline, covering ventral surface of midrib of thallus. Ventral scales absent or vestigal. Monoicous. Antheridia in a row along midline of the thallus, necks hyaline, visible throw the hole of lacunose thallus surface. Archegonia in deeply embedded rows, with purple or brownish necks, not prominent. Sporangia numerous, slightly bulging ventrally. Spores $65-95 \mu \mathrm{m}$ in diameter; triangular-globular; reddish- to dark brown; distal face convex, with irregular short and low toward margin lamellae, often united into incomplete alveolae; lamellae minutely papillose or spinulose in profile, without tubercles or spines at the angles; proximal face covered by simple or branched lamellae, occasionally uniting to form mostly incomplete areolae, with a distinctly trilete scar; wing 4-5 $\mu \mathrm{m}$ wide; wing margin crenulate to serrulate, sometimes erose. 


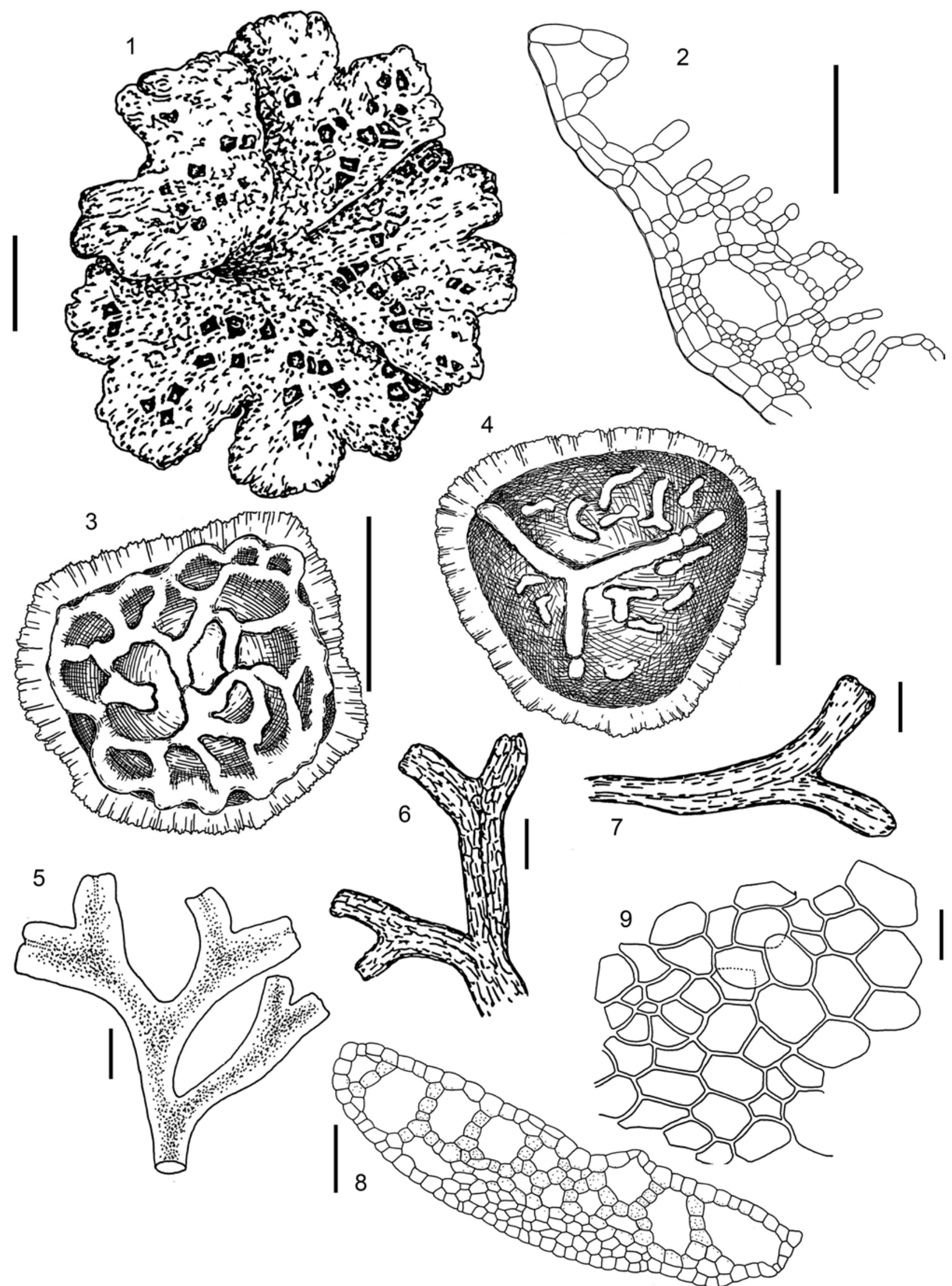

Figure 3 Riccia cavernosa Hoffm. (1-4): all from Kamchatka Territory, Bakalin, \#K67-1-03 (KPABG). 1 - habit of plant, dorsal view; 2 - thallus transverse section; 3 - spore, distal face; 4 - spore, proximal face. Scale bars: $1 \mathrm{~mm}$ for 1; $500 \mu \mathrm{m}$ for 2; $40 \mu \mathrm{m}$ for 3, 4; Riccia fluitans $\mathrm{L}$. (5-9): 5, 8-9 - from Primorsky Territory Borovichev \& Bakalin \#BB-1-14 (KPABG); 6-7 - from Primorsky Territory, 28. XI.1989, Gambaryan (VBGI) 5-7 - habit of plant, dorsal view; 8 - thallus transverse section; 9 - part of thallus dorsal epidermis. Scale bars: $300 \mu \mathrm{m}$ for $5-7 ; 200 \mu \mathrm{m}$ for 8; 40 $\mu \mathrm{m}$ for 9 
Differentiation. For a long time the species was regarded as the synonym of Riccia crystallina until Jovet-Ast (1964) found robust differentiation features between two taxa. They are as following: 1) R. cavernosa have green, yellowish green to grayish green color of upper surface thallus vs. bluish to grayish-green in R. crystallina; 2) air-chambers organized in (1-)2-3(-4) layers in the middle vs. air-chambers in 1-2 layers in the middle in R. crystallina; 3) thallus upper surface slightly to strongly and distinctly lacunose vs. persistent or very indistinctly lacunose towards the apex and often less conspicuously lacunose in older parts in R. crystallina; 4) spores incompletely alveolate, lamellae without tubercles and spines at the angles vs. strongly completely alveolate spores, lamellae with tubercles or spines at the angles in R. crystallina. Aside, R. cavernosa was sometimes confused with $R$. buebeneriana. However, $R$. cavernosa differs from latter by: 1) obcuneate or obovate and not canaliculate thalli branches vs. thick linear to lingulate, canaliculate in R. buebeneriana; 2) light green to yellowish green upper surface rarely with purplish secondary pigmentation vs. yellowgreen upper surface often with vinaceous red or purplish secondary pigmentation in R. buebeneriana; 3) spores incompletely alveolate vs. strongly completely alveolate spores in R. huebeneriana.

Ecology. Within area treated this species occurs exclusively on fine soil along watercourses or sometimes going away of the rivers by wet clayish roadsides for a some distance (as a rule not more than several tens meters). It prefers open and temporarily, but fairly regularly moistened habitats, that covering by water not only during spring flood, but also after heavy rains. Outside of the Russian Far East this species sometimes occupies clayey soil in rice and other kinds of cereal fields and may be found in similar conditions in area treated.

Distribution. The distribution of Riccia cavernosa may be treated as temperate circumpolar (Konstantinova 2000) or even subcosmopolitan (Jovet-Ast 1964, Paton 1999, Damsholt 2002, Stotler \& Doyle 2004, Furuki 2006). It occurs in various parts the land with the exception of high Arctic and Antarctic. Earlier record from Chukotka Autonomous District (Afonina \& Duda 1993) belongs to Sauteria alpina (Nees) Nees. In the Russian Far East the species is known from Kamchantka and Primorsky Territories (Fig. 2).

Specimens examined from area treated: RUSSIA. KamchatKa Territory, Central Kamchatka, Bystrynskyj District, Kamchatka River, $1.5 \mathrm{~km}$ downstream of the river crossing to Kozyrevsk, on oozy river bank, mixed with Riccia frostii and R. buebeneriana, 31.VII.2003, V.A. Bakalin K67-1-03 (KPABG; VBGI; as Riccia glauca and R. cavernosa); Primorsky Territory, Oktyabr' District, neighborhood of Pokrovka Settlement, bank of the Razdol'naya (Suifun) River, on soil, 22.IX.1985, M.S. Ignatov (MHA).

Other specimens examined: RUSSIA. RePUBLIC OF Tatarstan, Volzhsko-Kamskij State Nature Reserve, Saraly area, 26.IX.2002, G.P. Urbanavichyus (KPABG; VBGI); Astrakhan' Province, Astrakhan' State Nature Reserve, the delta of the Volga River, Damchikskij Area, with Riccia frostii, 11.X.2004, G.S. Taran (KPABG; VBGI); ibidem, with Riccia frostii, 17.X.2004, G.S. Taran (KPABG; VBGI); As- trakhan' City, bank of the Volga River, 17.X.2004, G.S. Taran (KPABG; VBGI); Novosibirsk Province, Novosibirsk City, bottomland of the Inya River, 2.IX.1991, G.S. Taran (KPABG; VBGI); REPUBLIC OF ALTAY, Tal'menskij District, neighborhood of Tal'menka Settlement, bottomland of the Chumysh River, 1994, G.S. Taran (KPABG; VBGI); Bijskij District, neighborhood of Stan-Bekhtemir Settlement, bottomland of the Biya River, 27.VIII.1994, G.S. Taran (KPABG; VBGI); Kur'inskij District, neighborhood of the Ozerki Settlement, bottomland of the Charysh River, with Riccia frostii, 21.VII.2006, G.S. Taran (KPABG; VBGI); ibidem, 5.VIII.1994, G.S. Taran (KPABG; VBGI); Kamenskij District, Ob `River flood-plane, eastern bank of Nizhnyaya Zalomnaya tributary, forbs-grass-sedge meadow, on the ground, 17.VIII.2006, G.S. Taran (VBGI); Tomsk Province, Aleksandrovsk District, lower course of the Lar'egan River, 10.IX.1990, G.S. Taran (KPABG; VBGI); ibidem, neighborhood of the Novonikol'skoe Settlement, Nizhnij Pyrchinskij Island, 30.VIII.1987, G.S. Taran (KPABG; VBGI); KAZAKHSTAN. Semipalatinsk ProVINCE, Semipalatinsk City, bottomland of the Irtysh River, 31.VII.1991, G.S. Taran (KPABG; VBGI); VostochnoKazakhstan Province, Markakol District, neighborhood of Buran Settlement, neighborhood of the Chernij Irtysh, 4.VIII.1992, G.S. Taran (KPABG; VBGI); ibidem, with Riccia frostii, 4.VIII.1992, G.S. Taran (KPABG; VBGI); CHINA. Inner Mongolia Province, Great Khingan Range, Huang Gang Liang Geological Park, north-facing slope covered by Betula platyphylla light forest, cliff crevices in part shade, mixed with Riccia frostii, 4.VIII.2010, V.A. Bakalin China31-5-10 (VBGI).

Riccia fluitans L., Sp. Pl. 1139. 1753. - Ricciella fluitans (L.) A. Braun, Flora 4: 757. 1821.

Description (Fig. 3: 5-9): Plants aquatic or terrestrial; aquatic plants in thin or dense loosely intricate mats, floating or attached to the substratum; terrestrial plants in loosely interwoven patches. Thalli medium-sized, 0.3-0.6(1) $\mathrm{mm}$ wide, $8-30 \mathrm{~mm}$ long; 2-6-times furcate; ultimate branches obovate or linear to lingulate; color of upper surface green or yellowish green, becoming pale brown or rarely reddish-brown with age; apex rounded to emarginate, usually dilated due to development of initial stages of new branches of the next generation; median furrow shallow and short (present near apex only) or almost absent; upper surface flat; smooth; reticulate; non-lacunose; conspicuous air-chambers visible throughout the dorsal epidermis, each air-chamber up to $300 \mu \mathrm{m}$ long and 70 $150 \mu \mathrm{m}$ wide; thallus margins rather thin, rounded. Dorsal epidermis unistratose; persistent; hyaline; hexagonal, 20-30 $\times 25-50 \mu \mathrm{m}$; thin- to medium thick-walled; pores simple; inconspicuous, surrounded by $4-5$ cells in $1(-2)$ rings. Cross-section 3-6-times wider than thick; semicircular, not furrowed; assimilation tissue 2/3-3/4 the thallus thickness in the middle; 70-320 $\mu \mathrm{m}$ thick; air-chambers large, polygonal, in 1-2 layers; ventral tissue very indistinct; $1 / 4-1 / 3$ of the thallus thickness in the middle. Ventral surface convex to plane; pale green; thallus branches midrib relatively poor-defined; $150-400 \mu \mathrm{m}$ thick in cross- 
section. Rhizoids sparse in terrestrial plants or lacking in aquatic plants. Ventral scales in a single median row, present mostly near branch apex, easily deciduous; semicircular to crescentic; hyaline to purplish; median cells $15-28 \mu \mathrm{m}$ wide and 30-46 $\mu \mathrm{m}$ long; marginal cells $8-10 \mu \mathrm{m}$ wide and $30-75 \mu \mathrm{m}$ long. Dioicous. Antheridia, archegonia and sporophytes unknown in the treated area. [Archegonia lies obliquely embedded in thallus, with the long, often dark purplish-pigmented neck in a small median depression. Spores (50-)55-75(-80) $\mu \mathrm{m}$ in diameter; triangularglobular; dark yellowish red; minutely verrucose; distal face alveolate, with 5-7 incomplete alveoli across diameter, each 8-16(-20) $\mu \mathrm{m}$ wide, mostly empty, walls fairly thick; proximal surface with fairly distinctly trilete scar, up to 10 , mostly incomplete areolae on each facet; wing $4-8 \mu \mathrm{m}$ wide, with single pore at marginal angles; sinuate (Schuster 1992, Paton 1999, Damsholt 2002)].

Differentiation and variation. Riccia fluitans is very variable and complex taxon consisting of 4-10 different 'narrow' species [R. canaliculata Hoffm. (Müller 1952, Paton 1999), R. duplex Lorb. ex Müll. Frib. (Müller 1952), R. jovetastiae E. Vianna (Vianna 1988), R. limicola Jovet-Ast (JovetAst 1978), R. luticola Na-Thalang (Na-Thalang 1980), R. multifida (Steph.) Steph. (Na-Thalang 1980), R. rhenana Lorb. ex Müll. Frib. (Müller 1952, Paton 1999), R. purpurascens Lehm. (Perold 1990), R. stenophylla Spruce (Schuster 1992), R. stricta (Gottsche, Lindenb. \& Nees) Perold (Perold 1990, 1999)] those sometimes are very difficult to distinguish from one another. As stressed by Berrie (1964) for reliable specimen identification R. fluitans s. 1., the cultivation under similar conditions is needed. Besides, the study of series of specimens by molecular methods is strongly appropriate.

R. fluitans differs from $R$. rhenana by: 1) narrow thallus branches, 0.3-1 mm wide vs. wider thallus branches, 0.5$1.2(-1.4) \mathrm{mm}$ in $\mathrm{R}$. rhenana; 2) conspicuous air-chambers visible throughout the dorsal epidermis, each air-chamber up to $300 \mu \mathrm{m}$ long and $70-150 \mu \mathrm{m}$ wide vs. larger air-chamber, to $500 \mu \mathrm{m}$ long and $150-350 \mu \mathrm{m}$ wide in R. rhenana. Riccia canaliculata was earlier regarded as the fertile terrestrial form of $R$. fluitans, but this point of view is mainly not followed now. The main differences between $R$. fluitans and R. canaliculata are: 1) regularly, but distantly furcate thalli vs. not regularly (although sometimes frequently) furcate in R. canaliculata; 2) flat to slightly concave thalli vs. distinctly furrowed towards apex in $R$. canaliculata; 3) conspicuous air-chambers visible throughout the dorsal epidermis vs. inconspicuous in R. canaliculata; 4) cross-section 3-6-times wider than thick vs. 1.5-2.5-times wider than thick in R. $c a-$ naliculata; 5) not visible apical ventral scales vs. apical scales visible in $R$. canaliculata.

The regional variation was noted for two areas in the Russian Far East. Some populations from Amur Province (13.VII.1985, V.V. Yakubov), Khabarovsk Territory (14. IX.1969, N.S. Probatova) and Primorsky Territory (17. IV.1992, S.K. Gambaryan) are characterized by the following features intermediate to R. stenophylla: 1) moderately narrow thallus 2.5-3-times wider than thick; 2) linear compact, inconspicuously reticulate thallus with longitudinally elongate air-chambers. Specimens collected in Pri- morsky Territory (20.VII.1973, L.V. Bardunov; 29.V.1998, V.Yu. Barkalov; 25.IX.1989, T.I. Nechaeva) are characterized by the complex of features merged with R. canaliculata, such as: 1) terrestrial plants in loosely intricate patches; 2) poorly furcate thalli; 3) occurrence both slightly concave thalli and more distinctly furrowed towards apex; 4) crosssection 2.5-4.5-times wider than thick. Taking into account the great variability of $R$. fluitans and poor material in aforementioned specimens, we consider both types of populations as $\mathrm{R}$. fluitans, although this question may require further studies.

Ecology. Despite relatively high frequency of occurrence of the species in the southern flanks of the area treated the ecological amplitude of $R$. fluitans is much narrower than that of R. buebeneriana. Contrary to the latter, R. fluitans much more depend on regular and heavy moistening (thus not only in the spring floods) of the substratum and do not go far away from the watercourses and pools. The basic habitat for the species in the Russian Far East are overlogged banks of pools and sluggishly flowing rivulets with more or less stable water level (with the exception of spring flood period), where the species grows on clayish soil or between small grasses and sedges partly immersed to the water. Much rarer the species grows on woody substrates (in constantly submerged state) or along peaty banks of small lakes. Like other taxa of the genus, the species prefers open habitats, but also tolerant to shady conditions and able to grow in the shadiest habitats among taxa of the genus known in the Russian Far East.

Distribution. Riccia fluitans has subcosmopolite (except for arctic and subarctic regions) distribution and known from Europe, Asia, Northern America, Northern Africa and New Zealand (Schuster 1992, Paton 1999, Damsholt 2002). Previously, Riccia fluitans was recorded for Amur Province (Bakalin 2010), Sakhalin Province (Kurils Islands, cf. Bakalin et al. 2009), Khabarovsk (Cherdantseva \& Gambaryan 1989) and Primorsky (Gambaryan 2000, 2001, Bakalin 2010) Territories. It has been confirmed from Amur Province, Khabarovsk and Primorsky Territories. In course of the field work of 2015 we also found the species in Iturup Island (Kurils Islands) (Fig. 2).

Specimens examined from area treated: RUSSIA. Khabarovsk Territory, Amur District, Bolon' Lake, Bolon'skij Fish Farm, 14.IX.1969, N.S. Probatova (VBGI); Komsomol'sk State Nature Reserve, Chenki River Mouth, floodplain lake, as floating, 12.VII.1984, V. Van, P. Kaledin (VBGI; KPABG); Amur Province, Arkharinsk District, Khingan State Nature Reserve, $40 \mathrm{~km}$ westward of Arkhara Settlement, river reach of Borzi River, 4.IX.1984, V.V. Yakubov (VBGI; KPABG); floodplain lake of Gryaznaya River, as floating, 13.VII.1985, V.V. Yakubov (VBGI); Zejsko-Bureinskij District, Gamakovka Village, small floodplain lake, 19.VI.1910, M. Korotkov (LE, KPABG, VBGI); PrIMORSKY TERritory, Khankajsky District, Dvoryanka Settlement vicinity, at bank of the Khanka Lake, among sedge and Irisplants, 29.V.1998, V.Yu. Barkalov (VBGI); neighborhood of Il'inka Settlement, Komissarovka River, 44³4'59,4"N $132^{\circ} 04^{\prime} 21,0^{\prime \prime} \mathrm{E}$, bank of the river, wet clayey on slope, in loosely interwoven patches, 8.XI.2014, E.A. Borovichev \& 
V.A. Bakalin \#BB-1-14 (KPABG; VBGI); Pozharsky District, Verkhnij Pereval Settlement vicinity, central part of the settlement, overgrowing pond, 25.VI.1993, S.K. Gambaryan (VBGI); wide valley bottom, on plant residues and base of tussock, 26.VI.1993, S.K. Gambaryan (VBGI); overgrowing of former riverbed, 26.VI.1993, S.K. Gambaryan (VBGI); Ignat'evka Settlement vicinity, near Emel'yanovskij open pit, overgrowing pond, on base of trees on bank, 28.XI.1989, S.K. Gambaryan (VBGI); overgrowing pond, as floating with Lemna minor, 28.IX.1989, S.K. Gambaryan (VBGI); Pogranichnyj District, Nesterovka Settlement, overgrowing pond, as floating, 25.IX.1989, T.I. Nechaeva (VBGI; KPABG); Ternejsky District, Ternej Settlement vicinity, left bank of the Serebryanka River, Yaponskoe Lake, mire in western part of the lake, 17.IV.1992, S.K. Gambaryan (VBGI); Khorolsky District, near Simakovka Settlement, mire, pure wet soil, 20.VII.1973, L.V. Bardunov (VBGI, KPABG); Ussurijskij District, near Razumovka Settlement, Vadimovskie lakes, on tussock, 27.IV.1924, A. Khakhina (KPABG); Sakhalin Province, Kurils Islands, Iturup Island, Medvezh'ya Bay, Strashnaya River Valley, on bare soil, 16.IX.2015, E.A. Borovichev \#BE 235-49-15 (KPABG).

Other specimens examined: RUSSIA. IRKUTSK PROVINCE, Khyngarcha River Valley, with Ricciocarpos natans, 15.VII.1926, V. Smirnova (KPABG; VBGI; as R. fluitans); Tyumen' Province, Uvatskij District, neighborhood of the Missiya Settlement, bottomland of the Irtysh River, 26.VII.2004, G.S. Taran (KPABG; VBGI; det. V.A. Bakalin); Tyva Republic, Todzhinskaya Kotlovina, bank of the Azas Lake, 14.VII.1999, V.A. Bakalin (KPABG; VBGI); Chita Province, Khentey-Chikoyskoye Nagorye, Kyra District, neighborhood of the Kyra Settlement, bottomland of the Kyra River, 17.VIII.2011, Yu.S. Mamontov (KPABG; VBGI; det. Yu.S. Mamontov); REPUBLIC OF KOREA, Jeju-Do, Seogwipo-si, Saekdal-dong, wetland, 25.VIII.2010, S.-S. Choi (VBGI; Hepaticae Korea Exsiccatae, Fasc. I. n. 70).

Riccia frostii Austin, Bull. Torrey Bot. Club 6: 17. 1875. - Riccia watsonii Austin, Bull. Torrey Bot. Club 6: 17. 1875. Riccia beckeriana C.A. Mey. ex Becker, Bull. Soc. Imp. Naturalistes Moscou 31(1): 84. 1858 nom. inval. (Art 43.2 (d)).

Description (Fig. 4: 1-4): Plants in grey-green to dark green, compact, in complete rosettes, often with purplish margins. Thalli dimorphic: female - small to medium-sized, $0.5-1.5(-2) \mathrm{mm}$ wide, $4-10 \mathrm{~mm}$ long vs. male thalli smaller than female; 2-4(-5)-times furcate; ultimate branches narrow, linear-lingulate to narrowly oblong; often lying parallel to each other or contiguous to partially overlapping; color of upper surface light to dark green with purplish secondary pigmentation in female thalli and usually strongly vinaceous in male; upper surface plane to convex; unclearly reticulate, slightly to strongly and distinctly lacunose in older parts; apex rounded-truncate to obtuse, sometimes shallowly emarginate; median furrow narrow, distinctly at apex only; thallus margins plane; rounded to subapiculate in cross section. Dorsal epidermis cells almost polygonal, shiny, 40-65(-70) $\mu \mathrm{m}$ wide and (30-)35-60 $\mu \mathrm{m}$ long; thin to thick-walled. Cross-section obtrapezioidal; $1.5-3$ times wider than thick; not furrowed; without lateral hairs; assi- milation tissue high, compact; $2 / 3$ the thallus thickness in the middle; $330-500 \mu \mathrm{m}$ thick; air-chambers narrow, vertical to inclined, either forming canals extending from ventral tissue to epidermis, or smaller, narrow polygonal, in 2-3 layers; ventral tissue parenchymatous, consisting of thin-walled cells; $1 / 5-1 / 4$ the thallus thickness in the middle. Ventral surface flat or weakly convex, green; thallus branches midrib compact, 540-750(-800) $\mu \mathrm{m}$ thick in cross-section; \pm relatively well defined. Rhizoids smooth only, hyaline, originated in ventral surface of midrib of thallus. Ventral scales absent or vestigial. Dioicous. Male thalli small, purple colored; antheridial necks purple, up to (80-)100-150 $\mu \mathrm{m}$ long. Female thalli larger, with strongly purple colored margins, with purple or brownish archegonial necks, not prominent. Sporangia numerous, bulging dorsally, after capsule wall being destroyed lying as dark spots over thallus surface. Spores (42-)48-52(-55) $\mu \mathrm{m}$ in diameter; triangular-globular; reddish- to dark brown; distal face convex; not reticulate, with irregular short, thin, sinuous, furcate and sporadic dispersed lamellae, in the center of the face occasionally delimit a few imperfect alveolae; proximal face with similar, although more sparing low lamellae; with distinct trilete scar; wing $2-3 \mu \mathrm{m}$ wide, granular, crenulate.

Differentiation. R. frostii may be easily mistaken with R. buebeneriana. The main differences are the following: 1) wider thalli, $0.5-1.5(-2) \mathrm{mm}$ wide vs. narrower thalli, $0.3-1(-1.2) \mathrm{mm}$ wide, in $\mathrm{R}$. buebeneriana; 2$)$ spore distal face not reticulate, with irregular short, thin, sinuous, furcate and sporadic dispersed lamellae, in the center of the face occasionally delimit a few imperfect alveolae vs. reticulate spore distal face with 6-8 alveoli and tubercles at the corners of the alveoli in R. buebeneriana; 3 ) smaller spores (42-)48-52 $(-55) \mu \mathrm{m}$ in diameter vs. larger spores(50-)60-70(-72) $\mu \mathrm{m}$ in R. buebeneriana.

Ecology. In general features the ecology of Riccia frostii is more or less similar to $\mathrm{R}$. buebeneriana (the former occupies virtually the same habitat in Western Siberia as $R$. buebeneriana in the Far East). In treated area, this species occurs in Kamchatka River Basin in similar conditions (loamy banks, logged with water at least in spring flood). However, in other regions this species, dissimilarly to the most of other localities in Russia, occupies places merely far of direct impact of the flowing water, like crevices in cliffs (Magadan Province). The same situation we observed in Great Khingan Range (China), where the species has rather meso-xerophitic ecological preference. We incluned to treat this anomaly as the result of competition between $R$. buebeneriana and $R$. frostii for most suitable habitats in the Russian Far East (in which $R$. buebeneriana is wining).

Distribution. Riccia frostii has boreo-temperate circumpolar distribution (Bakalin 2009), and known from the Middle Europe, the Mediterranean, Northern and Southern America, Asia and Northern Africa (Ladyzhenskaja 1952, Hässel de Menéndez 1963, Piippo 1990, Schuster 1992). In the Russian Far East, earlier, the species was reported from the Amur Province only (Ladyzhenskaja 1952). In the course of our studies, it has been recorded for Magadan Province and Kamchatka Territory (Fig. 5). 


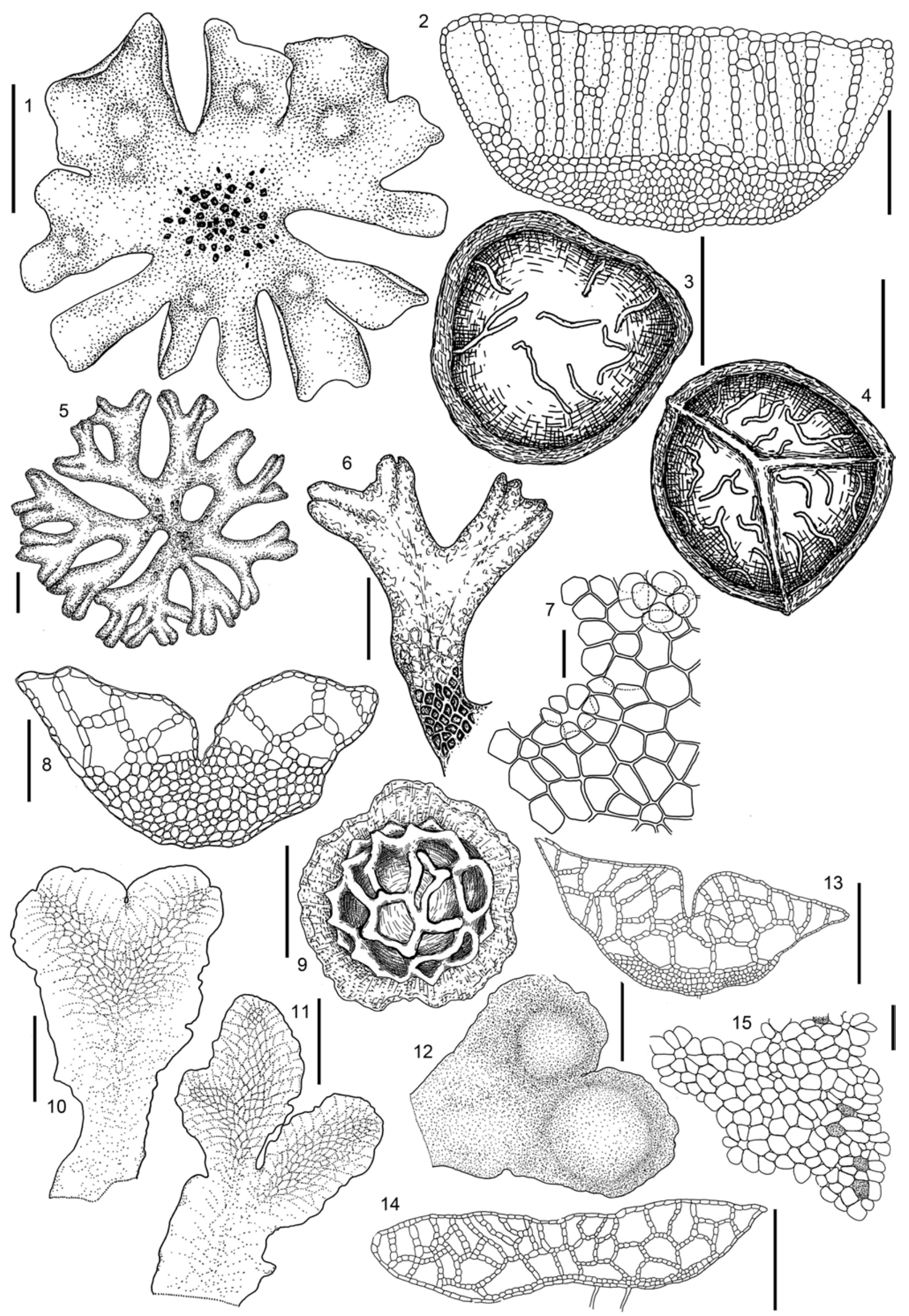


Type specimen examined: USA, NEVADA, S. Watson, s.n. (G 00281746, isotype).

Specimens examined from area treated: RUSSIA. *Kamchatka Territory, Central Kamchatka, Bystrynskyj District, Kamchatka River, $1.5 \mathrm{~km}$ downstream of the river crossing to Kozyrevsk, $\sim 56^{\circ} 05^{\prime} \mathrm{N}, 158^{\circ} 56^{\prime} \mathrm{E}$, on oozy river bank, mixed with Riccia cavernosa and R. buebeneriana, 31.VII.2003, V.A. Bakalin K67-1-03 (KPABG; VBGI); *Magadan Province, Upper Course of Kolyma River, Zamkovaya Mt. area, ca. $70 \mathrm{~km}$ downstream of Seimchan Settlement, 6321'16"N, 152³7'53"E, $180 \mathrm{~m}$ alt., fine-grained ground in crevice of coastal cliff, with sporophytes, 30.VII.2011, Seung Se Choi R5745 (VBGI, KPABG).

Other specimens examined: RUSSIA. AsTRAKHAN' Province, Astrakhansky State Nature Reserve, the delta of the Volga River, Damchikskij Area, with Riccia cavernosa, 11.X.2004, G.S. Taran (KPABG; VBGI); ibidem, with Riccia cavernosa, 17.X.2004, G.S. Taran (KPABG; VBGI); REpublic of Altay, Kur'inskij District, neighborhood of the Ozerki Settlement, bottomland of the Charysh River, with Riccia cavernosa, 5.VIII.1994, G.S. Taran (KPABG; VBGI); Novosibirsk Province, Suzunskij District, neighborhood of the Verkhnij Suzun Settlement, bottomland of the Ob' River, 8.IX.1994, G.S. Taran (KPABG; VBGI); TransBaikal Territory, neighborhood of the Tataurovo Settlement, bank of the Selenga River, 14.VIII.1999, V.A. Bakalin (KPABG; VBGI); Tyumen’ Province, Uvatskij District, neighborhood of the Missiya Settlement, bottomland of the Irtysh River, 17.VIII.2004, G.S. Taran (KPABG; VBGI); Tomsk Province, Aleksandrovsk District, neighborhood of the Larino Settlement, Kiselev's Island, 24.IX.1990, G.S. Taran (KPABG; VBGI); KAZAKHSTAN. SEMIPALATINSK Province, Semipalatinsk City, bottomland of the Irtysh River, 31.VII.1991, G.S. Taran (KPABG; VBGI); Vostochno-Kazakhstanskaya Province, Markakol District, neighborhood of Buran Settlement, neighborhood of the Chernij Irtysh, with Riccia cavernosa, 4.VIII.1992, G.S. Taran (KPABG; VBGI); CHINA. Inner Mongolia Province, Great Khingan Range, Huang Gang Liang Geological Park, north-facing slope covered by Betula platyphylla light forest, cliff crevices in part shade, mixed with Riccia cavernosa, 4.VIII.2010, V.A. Bakalin China31-5-10 (VBGI).

Riccia buebeneriana Lindenb., Nov. Actorum Acad. Caes. Leop.-Carol. German. Nat. Cur. 18: 504. 1836 [1837].

Description (Fig. 4: 5-9): Plants in thick loosely interwoven patches, forming complete to incomplete rosettes. Thalli small to medium-sized, $0.3-1(-1.2) \mathrm{mm}$ wide, 2-8 $\mathrm{mm}$ long; simple or 1-5-times furcate; ultimate branches thick, linear to lingulate; color of upper surface green or yellow green with vinaceous or reddish purple secondary pigmentation; apex rounded to emarginate; median furrow

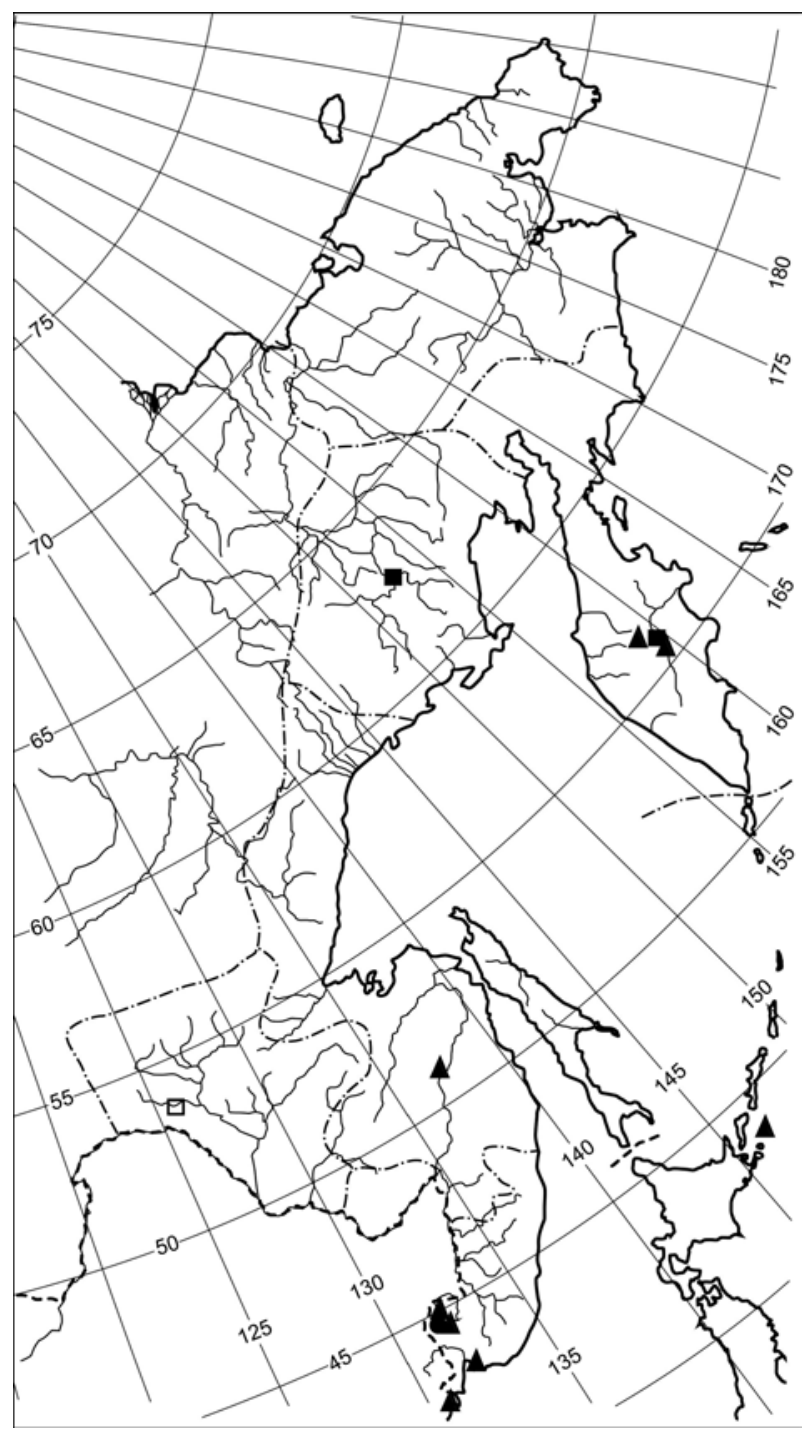

Figure 5 The distribution of Riccia frostii Austin - squares, Riccia buebeneriana Lindenb. - triangles, Riccia miyakeana Schiffn. - circles (open figures - literature records, filled figures - studied specimens)

narrow, distinct at apex, soon becoming shallow downward; upper surface flat to slightly convex; not reticulate; nearly smooth in primary stages of development, but with age becoming slightly to coarsely lacunose to alveolate in older parts; thallus margin plane; sometimes, rather rounded to subacute; thick; often weakly turned dorsally. Dorsal epidermis unistratose; hyaline; cells rounded to subquadrate, 25-35 $\times 25-32 \mu \mathrm{m}$; thin- to moderately thick-walled. Crosssection as wide as thick to 3 -times wider than thick; semicircular to wide semicircular, evidently furrowed; without lateral hairs; assimilation tissue high, compact; $2 / 5-2 / 3$ the thallus thickness in the middle, in older parts often narrower; 150-480 $\mu \mathrm{m}$ thick; air-chambers large, polygonal, in (1-)2-3(-4) layers; ventral tissue parenchymatous, con-

Figure 4 Riccia frostii Austin. (1-4): all from Kamchatka Territory, Bakalin, \#K67-1-03 (KPABG). 1 - habit of plant, dorsal view; 2 - thallus transverse section; 3 - spore, distal face; 4 - spore, proximal face. Scale bars: 2 mm for 1; $300 \mu \mathrm{m}$ for 2; $20 \mu \mathrm{m}$ for 3, 4; Riccia huebeneriana Lindenb. (5-9): all from Primorsky Territory, Bakalin \#P74-3-08 (VBGI). 5 - habit of plant, dorsal view; 6 - part of thallus, dorsal view; 7 - part of thallus dorsal epidermis; 8 - thallus transverse section; 9 - spore, distal face. Scale bars: $1 \mathrm{~mm}$ for $5-6 ; 300 \mu \mathrm{m}$ for 8 ; $50 \mu \mathrm{m}$ for $7 ; 30 \mu \mathrm{m}$ for 9 ; Riccia miyakeana Schiffn. (10-15): all from Primorskij Territory, Borovichev \& Bakalin \#BE-5/1-12 (KPABG). 10-11 - habit of plant, dorsal view; 12 - habit of plant, ventral view; $13-14$ - thallus transverse section; 15 - part of thallus dorsal epidermis. Scale bars: $1 \mathrm{~mm}$ for $10-12$; $600 \mu \mathrm{m}$ for $13-14 ; 120 \mu \mathrm{m}$ for 15 
sisting of thin-walled cells; $1 / 3-3 / 5$ the thallus thickness in the middle. Ventral surface convex; green. Thallus branch midrib \pm relatively ill-defined; $250-600 \mu \mathrm{m}$ thick in cross-section. Rhizoids smooth and pegged, hyaline, occur sporadically along ventral surface of midrib of thallus. Ventral scales in one single median row or in two lateral rows of half-scales; hyaline to purplish; large. Monoicous. Antheridia immersed, separated surrounded by thallus tissue; necks purplish, prominent; up to 110-140 $\mu \mathrm{m}$ long. Archegonia situated along thallus midline, with necks purple; up to 190-230 $\mu \mathrm{m}$ long. Sporangia numerous; prominent ventrally as hemispherical swelling; spores exiting through holes in ventral epidermis. Spores (50-)60-70(-72) $\mu \mathrm{m}$ in diameter; triangular-globular; yellowish brown, translucent; distal surface alveolate, with 6-8 alveoli, each 7-12 $\mu \mathrm{m}$ wide, with tubercles at the corners of the alveoli; proximal surface with a trilete scar, partially to completely alveolate; wing 2-6 $\mu \mathrm{m}$ wide, narrow, crenulate.

Differentiation and variation. Sterile forms (relatively rare case for this freely fertilized taxon) of $R$. buebeneriana with non-lacunose persistent thallus surface are difficult or even impossible to distinguish from $\mathrm{R}$. fluitans. In the most cases $R$. buebeneriana differs from latter by: 1) presence of numerous sporangia vs. commonly sterile of $\mathrm{R}$. fluitans; 2) thalli 2-8 mm long vs. 10-30 mm long in R. fluitans; 3) thallus distinctly furrowed towards apex vs. not furrowed one in R. fuitans. In addition R. huebeneriana may be confused with $R$. rhenana, which differs from latter in: 1) non-reticulate thallus dorsal surface vs. distinctly reticulate one in $R$. rhenana; 2) thallus cross-section as wide as thick to 3-times wider than thick, vs. thallus 5-8-times wider than thick in R. rhenana. Differences from $R$. cavernosa as well as $R$. frostii were disscused above. American populations are treated as a separate subspecies - Riccia huebeneriana subsp. sullviantii (Austin.) R.M. Schust. The latter differs from subsp. buebeneriana by: 1) green plants, without purplish coloration or secondary coloration is rare and local; 2) thin ventral tissue in thallus cross-section and 3) larger spores, 65-75(-78) $\mu \mathrm{m}$ in diameter (Schuster 1992). The latter variation may be expected in the northern part of the Russian Far East.

This species is polymorphic in thallus coloration that varies from violet in drier and open sites to deep green, without secondary pigmentation in more moist and shady habitats. The noted coloration variability may depend on not only moistness of habitat but, in a manner, from season to season. We repeatedly observed purple colored forms of the species in Primorsky Territory just before winter time, when daily temperature becomes slightly negative (in Celsius scale).

Ecology. This is the most common species of the genus in the Russian Far East. It occupies clayey soil in regularly moistened banks of large pools, sluggishly flowing watercourses, large rivers with distinct spring flood period. It is also merely common in clayish soils in agriculture lands and wet roadsides in Khanka lowland of Primorsky Territory (including those moistened by rains only). The species prefers open sites and rarely occurs in the shade under $S a$ lix and Alnus hirsuta canopy. In Kamchatka Territory the species occupies such peculiar habitat as banks of thermal pools in areas of active volcanism, where may be found in chemically aggressive and warm substratum (up to $40^{\circ} \mathrm{C}$, containing arsenic).

Distribution. Riccia buebeneriana has temperate circumpolar distribution (Bakalin 2009), and known from Europe, Asia and Northern Africa (Piippo 1990, Paton 1999, Damsholt 2002, Schumacker \& Váňa 2005). Earlier in the Russian Far East Riccia buebeneriana was recorded for Kamchatka Territory (Potemkin 2003), Amur Province (Konstantinova et al. 2002), Sakhalin Province (Bakalin 2009) and a few localities in Primorsky Territory (Gambaryan 1992; Andrejeva 2009; Bakalin 2010). In the course of our studies it has been confirmed from Kamchatka and Primorsky Territories and is firstly reported from Khabarovsk Territory. Bakalin (2009) published Riccia buebeneriana in VIII fascicle of the Hepaticae Rossicae Exsiccatae from Shikotan Island, but in the paper on bryophyte flora of South Kuril Islands (Bakalin et al. 2009) he erroneously cited the same specimen as R. fluitans. Indeed, the latter species is still not found in Shikotan Island (although likely may be found) where R. buebeneriana only known (Fig. 5).

Type specimen examined: GERMANY, ODENWALD, Allemagne, J.W.P. Huebener, s.n. (G 00115572, isotype).

Specimens examined from area treated: RUSSIA. Kamchatka Territory, Central Kamchatka, Bystrynskyj District, Kamchatka River, $1.5 \mathrm{~km}$ downstream of Kozyrevsk, on oozy river bank, mixed with Riccia cavernosa and R. frostii, 31.VII.2003, V.A. Bakalin K67-1-03 (KPABG; VBGI); Kireunskie hot springs, on the bank of hot spring, 19.VII.2009, V.Yu. Barkalov (VBGI, KPABG; as Riccia sp.); 28.VII.2009, V.Yu. Barkalov (VBGI, KPABG); KHABArovsK Territory, Komsomol`sk State Nature Reserve, silty border of channel of Goryun River, 15.VIII.1980, T.F. Shelestova (VBGI); Primorsky Territory, suburbs of Vladivostok, clayish soil on slope to Sedanka River, 12.VIII.2006, V.Ya. Cherdantseva (VBGI; det. V.A. Bakalin); slope to Sedanka River, on the river bank, 23.VIII.1952, D.P. Vorob’jov (VBGI); Khanka District, ca. $7 \mathrm{~km}$ to northward of Novokachalinsk, edge of arable field, on soil, with sporogonia, 19.X.2008, V.A. Bakalin \#\#P74-1-08, 74-2-08, 74-3-08, 74-4-08 (VBGI, KPABG); Mel'gunovka Creek valley, along ground in wet meadow, clayish wet roadside, 18.X.2008, V.A. Bakalin \#P73-1-08 (VBGI, KPABG); ca. $2 \mathrm{~km}$ to Nerpa, Cruglaya Bay, near base rocky seashore, on wet humic rocks, mixed with Conocephalum salebrosum, 9.VIII.1986, S.K. Gambaryan (VBGI); SAkhalin Province, Kurils, Shikotan Island, flood-plain of Osrovnaya River, AlnusSalix thickets with cover of tall herbs, track of old road, 1.IX.2007, V.A. Bakalin \#\#K55-1-07; 55-5-07; 55-6-07 (VBGI; KPABG).

Other specimens examined: RUSSIA. KHANTY-MANsijsk National Area, Surgut District, neighborhood of the Surgut City, bottomland of the Ob' River, 6.IX.2004, G.S. Taran (KPABG; VBGI). JAPAN. Miyazaki PrefecTURE, Nichinan, Obi, old samurai Obijo Castle ruins, moist stone wall of artificial construction, in part shade, 6.II.2014, V.A. Bakalin, \#L1-10-14 (VBGI; KPABG; as Riccia sp.); Niigata Prefecture, Nagaoka-shi, Teradomari, on soil in rice field, 22.VIII.2015, T. Yamaguchi \#35697 (HIRO 
1029703; as Riccia); Aichi Prefecture, Aisai-shi, Nichihocho, on wet soil in rice plant field, 24. IX.2007, K. Nishimura \#07-22 ex Herb. K. Yamada in hb. H. Deguchi \#37868 (HIRO247327).

Riccia miyakeana Schiffn., Österr. Bot. Z. 49 (11): 386. 1899.

Description (Fig. 4: 10-15): Plants in diffuse pale greenish to whitish patches. Thalli medium-sized, 1.2-3.0 $\mathrm{mm}$ wide, 4-7(-10) mm long; 1-2-times furcate; ultimate branches oblong obcordate; color of upper surface light green, sometimes with vinaceous tint along margins; whitish green to pale yellow-white in older parts; upper surface convex; strongly reticulate, not lacunose; apex thick, rounded or shortly emarginate; median furrow distinct at apex, downward immediately become shallow and vanishing or (rarer) continues along most of thallus length; thallus margins whitish, not incurved, rounded, obtuse in cross section. Dorsal epidermis unistratose; hyaline; cells subquadrate to isodiametric, shiny, 35-55 $\mu \mathrm{m}$ wide; thinto with moderately thickened walls. Cross-section hemispheric, furrowed; 3-5 times wider than thick; assimilation tissue high, often occupying most of thickness of thallus; $400-800 \mu \mathrm{m}$ thick; $3 / 4-4 / 5$ of the thallus thickness in the middle; air-chambers wide; large, polygonal; arranged in 2-4 layers in the middle and in 1-2 layers in the wing; ventral tissue \pm relatively poor-defined; $1 / 5-1 / 4$ the thallus thickness in the middle. Ventral surface strongly convex, green; thallus midrib fleshy to spongy, 600-900 $\mu \mathrm{m}$ thick in cross-section; relatively well-defined. Rhizoids smooth and pegged, hyaline to whitish, scattered along ventral surface of midrib of thallus. Ventral scales present mostly near apex; conspicuous; hyaline, shine, narrowly lunate, easily deciduous. [Monoicous. Sporangia prominent ventrally as hemispherical swellings. Spores large, 80-90(-100) $\mu \mathrm{m}$ in diameter; dark red to reddish brown; distal face alveolate, with 8-9 or 9-11 alveoli across the face; lamellae with tubercles or spines at the angles; wing wide; wing margin spinulose (Schiffner 1899; our data based on studied Japanese specimens)].

Differentiation and variation. The only one locality (Il'inka River flood plain) is known in the Russian Far East. We refer studied specimens to Riccia miyakeana with some doubts. Moreover, they may belong to new, previously undescribed taxon, but not to true $R$. miyakeana. The plants from cited locality are characterized by: 1) growing in diffuse patches; 2) thallus upper surface light green, sometimes with lateral vinaceous tint, strongly whitish green to yellowwhite in older parts, convex and strongly reticulate, not lacunose; 3) median furrow distinct at apex, immediately behind apex shallow and vanishing or continuing along the most of thallus length; 4) the cross-section 3-5 times wider than thick; 5) assimilation tissue consist of wide and large air-chambers, 2-4-layered in the middle and 1-2-layered in the wing; 6) ventral tissue \pm relatively poor-defined.

Riccia miyakeana may be confused with $R$. buebeneriana, although differs from the latter by: 1) distinctly reticulate and very soft thallus upper surface, vs. non-reticulate in $R$. buebeneriana; 2) thallus upper surface not lacunose even in older parts, vs. not or very indistinctly lacunose in younger segments, but with age in older parts becoming distinctly lacunose to alveolate in $R$. buebeneriana; 3) thallus $1.2-3 \mathrm{~mm}$ wide, vs. narrower thallus $0.3-1(-1.2) \mathrm{mm}$ in $\mathrm{R}$. buebeneriana; 4) in cross-section 3-5 times wider than thick, vs. as wide as thick to 3-times in R. buebeneriana.

Ecology. The only habitat we observed in the Russian Far East is the very wet swampy meadow in large hollow (becoming a pool in rainy season), where the species grew in more or less shady conditions on litter and between stems of Carex and Calamagrostis hummocks. The population size in that locality is the subject of great variation, and when (since we collected sterile material only) we visited the same area at the next year we were not able to find that species at all, although one year before it was quite common. The only locality of the species is in the Khanka lowland - the most continental area in the southern flank of the Russian Far East and also the refugium for a lot of vascular plant species with presumable circum-Tethian origin (Kozhevnikov 2007).

Distribution. Riccia miyakeana was described by V. Schiffner from Botanical Garden of Tokyo (Japan) basing on specimens collected by Miyke (Schiffner 1899). After, it was found as sporadic in Shikoku, Kyushu and Honshu (Yamada \& Iwatsuki 2006; our data), and then included to the list and was treated as a Japanese endemic taxon (Higuchi 2011). This is the first report of Riccia miyakeana for Russia and outside of Japan (Fig. 5).

Specimens examined from area treated: RUSSIA. Primorskij Territory, Khanka District, Il'inka Settlement

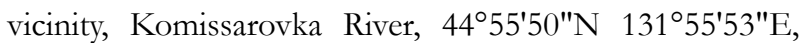
ca. $83 \mathrm{~m}$ alt., swampy meadow in hollow, in diffuse patches, 18.X.2012, E.A. Borovichev \& V.A. Bakalin \#\#BE5/1-12, BE5/11-12 (KPABG; VBGI).

Other specimens examined: JAPAN, NiIGATA PREFECTURE, Nagaoka-shi, Teradomari, on soil in rice field, 22.VIII.2015, T. Yamaguchi \#35696 (HIRO 1029702); Tsubame-shi, Watabe, on soil in rice field, 22.VIII.2015, T. Yamaguchi \#35728 (HIRO 1029734); Kanagawa PrefeCTURE, Kamanura-shi, near Kenchaji Temple, on soil, at open place, 6.IX.2001, T. Furuki (TNS 175583); KoCHI PREFECTURE, Nagaoka-gun, Motoyama-cho, Sukefuji, on moist soil in rice field, 24.I.2008, H. Deguchi \#37896 (HIRO247484); Tokio, Oshima-cho, Izu Island, Furusatomura, 25.XI.2004, M. Higuchi (TNS 173582); Kagoshima Prefecture, Oshima isl., Furusato-mura Park, on soil at garden, 25.XI.2004, T. Furuki (TNS 175662); Miyazaki Prefecture, Nichinan, Obi, Obi Junior high school, 19.IX.1940, S. Hattori (TNS, 039147); Saitama Prefecture, Chichibu, Ontaki-mura, Kaminakao, 7.VII.1957, H. Inoue (TNS 206258).

Riccia nipponica S. Hatt., J. Hattori Bot. Lab. 9: 38. 1953.

Description (Fig. 6: 1-11): Plants crystalline, in rosettes or hemirosettes, not forming pure mats. Thalli medium-sized, 2.5-5.0 mm wide, 5-7 mm long; 2-4 times furcate; ultimate branches short, wide, obcordate; upper surface light green to somewhat bluish green, in older parts becoming whitish or yellowish; not or slightly lacunose towards the apex and sparsely lacunose in older parts; apex thick, rounded to shortly emarginate; median furrow dis- 

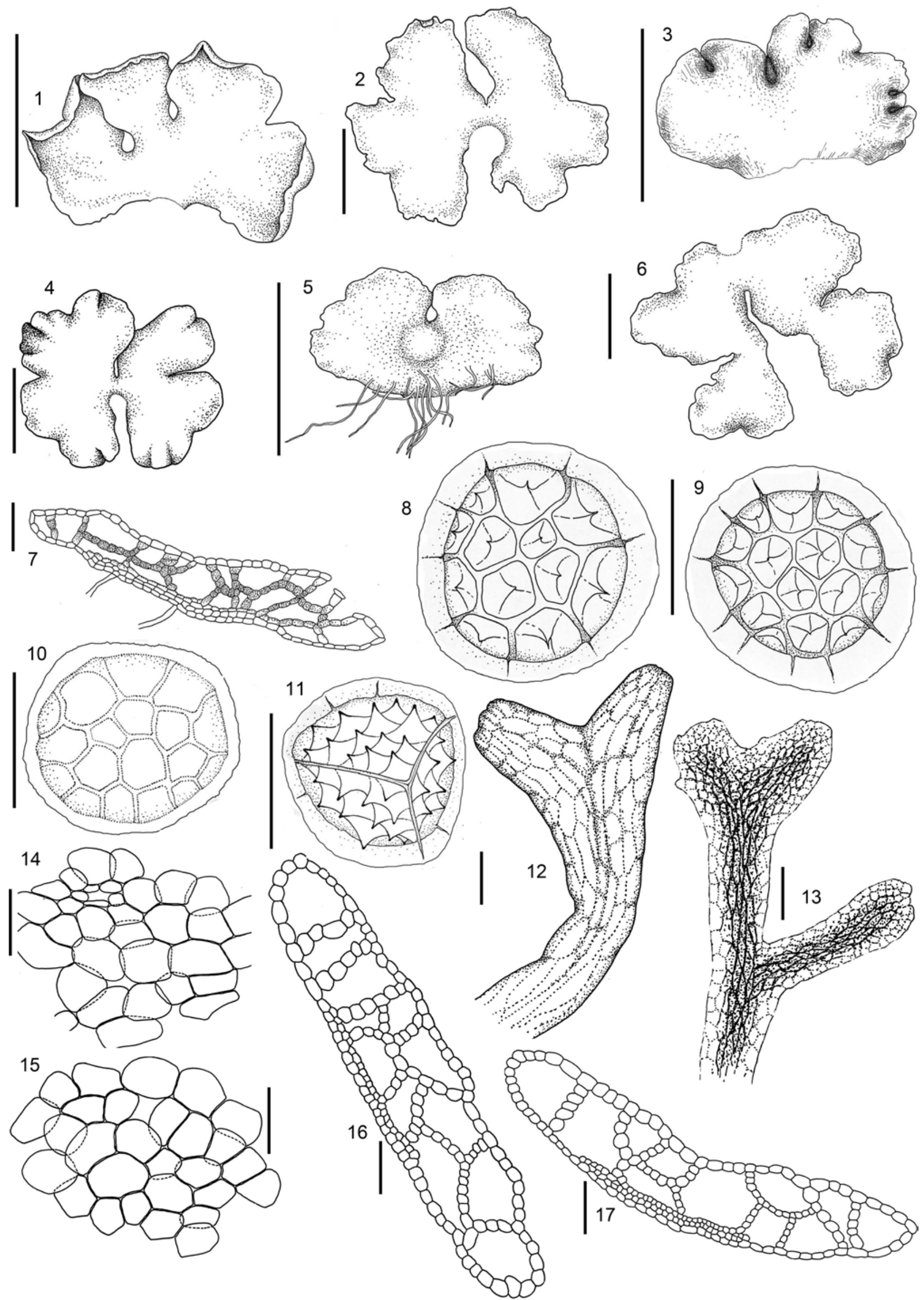
tinct at apex, shallow and disappearing downward; thallus margins raised, not incurved, obtuse. Dorsal epidermis cells almost globular, shiny, 45-56 $\mu \mathrm{m}$ wide; thin-walled. Thallus cross section elliptic, not furrowed; 3-5 times wider than thick; assimilation tissue compact; 400-550(600) $\mu \mathrm{m}$ thick, occupying $2 / 3-3 / 4$ the thallus thickness in the middle; air-chambers narrow near apex and wider toward base, in 1-2 layers in the middle. Ventral tissue parenchymatous, consisted by thin-walled cells; occupies $1 / 4-1 / 3$ of the thallus thickness in the middle. Ventral surface green; thallus midrib fleshy, 600-800 $\mu \mathrm{m}$ thick in cross-section; relatively well-defined. Rhizoids smooth and pegged, hyaline, covering ventral surface of midrib of thallus. Ventral scales developed mostly near apex; inconspicuous (hardly visible); hyaline, minute. Monoicous. Antheridia in two lateral rows along thallus midline, necks hyaline, up to 150-180 $\mu \mathrm{m}$ long. Archegonia along thallus middle, with necks purple-brown colored, up to 180-210 $\mu \mathrm{m}$ long. Sporangia numerous, dorsal, slightly protruding ventrally. Spores $55-70(-78) \mu \mathrm{m}$ in diameter; light to dark yellowish or brownish; distal surface alveolate, with laminae forming 4-5(-6) complete, round alveoli across the face, 8-10(-12) $\mu \mathrm{m}$ in diameter; lamellae thin and low, usually with a spine in the center of alveola; proximal surface similar to distal surface or less regularly reticulate, with a distinct trilete scar; wings (4-) $6-8(-12) \mu \mathrm{m}$ wide; wing margin crenulate to spinulose, sometimes erose.

Differentiation and variation. Riccia nipponica belongs to Riccia crystallina-complex where morphologically is most similar to R. crystallina and R. cavernosa. R. nipponica differs from $R$. cavernosa in: 1) color of thallus upper surface light green to somewhat bluish green, in older parts becoming whitish or yellowish vs. green, yellowish, or light- to grayish green, often with reddish secondary pigmentation in $\mathrm{R}$. $c a$ vernosa; 2) dorsal epidermis not or slightly lacunose towards apex and sparsely lacunose in older parts vs. slightly to very distinctly lacunose or alveolate in R. cavernosa; 3) thallus cross-section, width/thickness ratio $3-5$ vs. 1.5-2.5(-4.0) in R. cavernosa; 4) texture of thallus glistening and crystalline vs. not crystalline in $\mathrm{R}$. cavernosa; 5) spore distal face with 4-5 large, complete alveoli across spore diameter, without tubercles or spines at the angles vs. lamellae irregular, short and low toward margin, often forming incomplete alveoli, without tubercles or spines at the angles. The main differences between $R$. nipponica and $R$. crystallina are the following: 1) color of thallus upper surface light green to somewhat bluish green, in older parts becoming whitish or yellowish vs. bluish to grayish but turning whitish upon drying in the field in R. crystallina; 2) thallus cross section, width/thickness ratio $3-5$ vs. $2.5-4.0$ in $R$. crystallina; 3 ) spore distal face with 4-5 large, complete alveoli across spore diameter vs. with 7-10 complete small alveoli across spore diameter in R. crystallina; 4) with spine in center of alveoli, but not in angles vs. with tubercles or spines at the angles in $\mathrm{R}$. crystallina; 5) widther of spores wings: (4-)6-8(-12) $\mu \mathrm{m}$ vs. 3-4(6) $\mu \mathrm{m}$ in R. crystallina.

Studied specimens vary in spore size, the number of alveoli across spore diameter and width of spore wing. The spores from Khabarovsk Territory specimen are smaller ((53-)55-65 $\mu \mathrm{m}$ in diameter) than in Japanese and Chinese specimens $(65-78 \mu \mathrm{m})$. Typically, as described by Shimizu \& Hattori (1953), spore distal face has 4 large complete alveoli across spore diameter, but in our studied specimens we found 4(-5) large complete alveoli in Japanese plants (Hattori, 7 March 1950), 4-5(-6) complete alveoli in plants from Khabarovsk Territory and four large complete alveoli in Chinese plants. The width of spore wing varies even within one sporangium from 4-6 $\mu \mathrm{m}$ to $8-10(-12) \mu \mathrm{m}$. Unlikely to specimens from the Russian Far East and Japan, the plants in Chinese specimen have noticeable lacunose dorsal surface that impressed R. cavernosa appearance. However, other features like spore size and ornamentation coincide with plants from Japan described by Shimizu \& Hattori (1953). These discrepancies may be probably explained by wider morphological variability than it was suggested before (Shimizu \& Hattori 1953).

Ecology. The habitat of the species in the Russian Far East situated within so-called 'Ussuri taiga' zone (mixed coniferous-broadleaved forest in contact zone of Temperate and Boreal vegetation), where the species occupied sandyloam stream bank together with R. frostii. Probably the origin of this occurrence has relict nature and reflects ancient contacts of the flora with warm-temperate vegetation in Eastern Asia.

Distribution. Earlier, R. nipponica was treated as a Japanese endemic and the taxon merely common in Japan (Yamada \& Iwatsuki 2006, Higuchi 2011; our data). Recently, the species was also recorded for Guizhou Province of China and for the Russian Far East (Bakalin et al. 2015) (Fig. 7).

Type specimen examined: JAPAN, MIYAZAKI PreFECTURE, Obi-cho, Minaminaka-gun, on soil, 5.II.1953, S. Hattori \& D. Shimizu (NICH 51535, holotype).

Specimens examined from area treated: RUSSIA, Khabarovsk Territory, Komsomolsk State Nature Reserve, Amur River Upland, mouth of Gorin River, Bichi Island ca $70 \mathrm{~km}$ downstream of Seimchan Settlement, sandy-loam bank, mixed with R. frostii, with sporophytes, 16.IX.1986, Shelestova, s.n. (VBGI; as R. buebeneriana).

Other specimens examined: CHINA, Guizhou ProvINCE, Kaijang County, Xiang Zhi Stream, agricultural land in country side, clay in the rice field margin, with sporophytes, 19.XI.2013, V.A. Bakalin \#China52-1-13 (VBGI; KPABG); JAPAN, Miyazaki Prefecture, Obi-cho, Minaminaka-gun, on soil, 5.II.1953, S. Hattori \& D. Shimizu \#51535 (NICH, holotype of R. nipponica); FuKUOKa PREFECTURE, 5.I.1958, Yu. Kuwahara (LE, KPABG, VBGI -

Figure 6 Riccia nipponica S. Hatt. (1-11): 1-2, 5-7, 9-11 from Khabarovsk Territory, Shelestova, 16.IX.1986, (KPABG); 3-4, 8 from Guizhou Province, Bakalin, 19.XI.2013 (VBGI). 1-4, 6- habit of plant, dorsal view; 5 - habit of plant, ventral view; 7 - cross section of thallus; 8-10 - distal face of spores; 11 - proximal face of spores. Scale bars: $3 \mathrm{~mm}$ for 1-6; $600 \mu \mathrm{m}$ for 7; $45 \mu \mathrm{m}$ for 8-11; Riccia rhenana Lorb. ex Müll. Frib. (12-17): all from Primorskij Territory, Borovichev \& Bakalin \#BB-1-14 (KPABG). 12-13 - habit of plant, dorsal view; 14-15 - part of thallus dorsal epidermis; 16-17 - thallus transverse section. Scale bars: $600 \mu \mathrm{m}$ for $13 ; 400 \mu \mathrm{m}$ for $12 ; 300 \mu \mathrm{m}$ for $16-17 ; 60 \mu \mathrm{m}$ for 14-15 


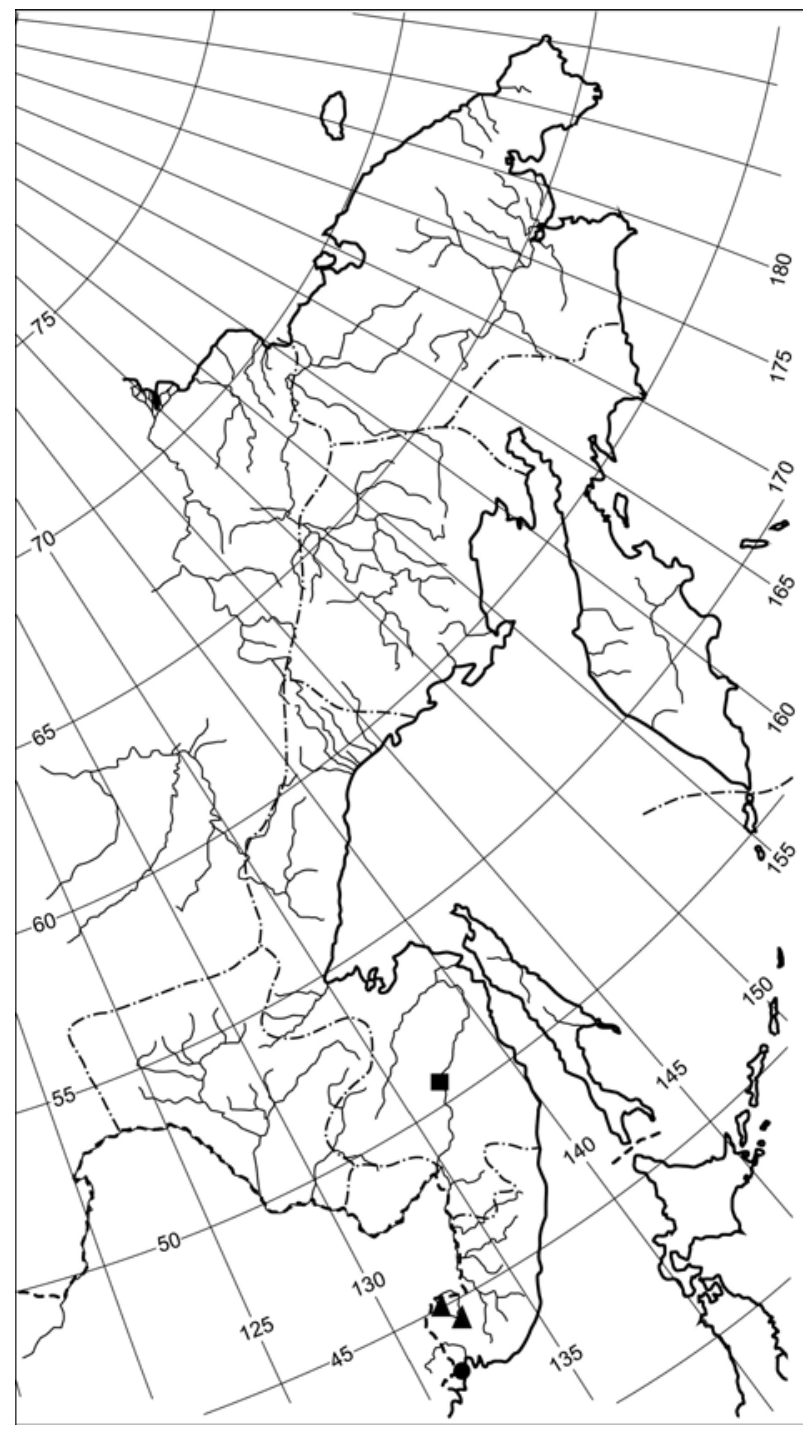

Figure 7 The distribution of Riccia nipponica S. Hatt. - squares, Riccia rhenana Lorb. ex Müll.Frib. - triangles, Riccia beirichiana Hampe ex Lehm. - circles (open figures - literature records, filled figures studied specimens)

Hepaticae Japonicae Exsiccatae, Ser. 1: 22); Ibaraki PREFeCture, Joshu-shi, Higashi-Mati, Fukuoka, near Toshuko Bridge, 13.XII.2007, Q. Latiff (HIRO 247230); HiroshIMA Prefecture, Higashi-hiroshima-shi, Kagamiyama, on soil, 19.IV.2001, M. Itouga \#3826 (HIRO; as Riccia); KOCHI PREFeCTURE, Nagaoka-gun, Motoyma-cho, Sukefuji, on moist soil in rice field, 24.I.2008, H. Deguchi \#37896 (HIRO 247484); Saitama Prefecture, Saitama-shi, Midori-ku, Minuma, on moist soil in nursery garden, 8.XI.2007, M. Itouga \#4067 (HIRO).

Riccia rhenana Lorb. ex Müll.Frib. Hedwigia 80(1/2): 94. 1942 [1941].

Description (Fig. 6: 12-17): Plants terrestrial or aquatic (latter phase is unknown in our area); in loosely interwoven patches or forming incomplete rosettes. Thalli medium-sized, 0.8-1.2 mm wide, 5-12 mm long; 1-4-times furcate; ultimate branches lingulate; color of upper surface dark to pale green and brownish; glistening; apex rounded, emarginate; slightly ascending; median furrow shallow and present only near the apex, or nearly absent; upper surface flat, smooth, strongly reticulate; not lacunose; air-chambers conspicuous, visible throughout the dorsal epidermis, each air-chamber 290-750 $\mu \mathrm{m}$ long and 150-322 $\mu \mathrm{m}$ wide; thallus margins rather thin, rounded. Dorsal epidermis persistent; hyaline; composed by hexagonal cells, 28-42×32-48 $\mu \mathrm{m}$; with thin- to moderately thickened walls; pores simple; inconspicuous, surrounded by $4-5$ cell ring. Cross-section 4.4-7.1-times wider than thick; not furrowed; elliptical; assimilation tissue $4 / 5$ the thallus thickness in the middle; $150-350 \mu \mathrm{m}$ thick; air-chambers large, polygonal, arranged in 1-2 layers; ventral tissue very indistinct; $1 / 5-1 / 4$ the thallus thick in the middle. Ventral surface convex to plane; pale green to rose; thallus branches midrib relatively poor-defined; $180-400 \mu \mathrm{m}$ thick in cross-section. Rhizoids scarce; smooth and pegged. Ventral scales in a single median row, present mainly near branch apex; semicircular to lunate; hyaline to purplish; median cells $24-38 \mu \mathrm{m}$ wide; marginal cells 9-12 $\mu \mathrm{m}$ wide and 40-75 $\mu \mathrm{m}$ long. Antheridia, archegonia and sporophytes unknown.

Differentiation and variation. $R$. rhenana belongs to the Riccia fluitans-complex and represents diploid form of latter (Berrie 1964). Terrestrial forms of $R$ rhenana differs from R. fluitans in: 1) more robust thalli vs. more delicate in R. fluitans; 2) wider thallus branches, $0.8-1.2 \mathrm{~mm}$ vs. narrower thallus branches, $0.3-1 \mathrm{~mm}$ wide in $\mathrm{R}$. fluitans; 3) crosssection 4-7 times wider than thick vs. 3-6 times wider than thick in R. fluitans; 4) larger air-chambers (in the view from dorsal side), to $750 \mu \mathrm{m}$ long and 150-350 $\mu \mathrm{m}$ wide vs. smaller up to $300 \mu \mathrm{m}$ long and $70-150 \mu \mathrm{m}$ wide vs. in R. fluitans.

Ecology. The ecology of the species in area treated is poorly understood. It seems to be similar to that of R. fluitans, with the exception of the most 'xeric' habitats of the latter. The species occurs in open to partly shaded loamy and clayey banks of rivers in Khanka lowland, thus in the same area (but not habitat!) with $R$. mayakeana.

Distribution. R. rhenana has temperate, probably Holarctic distribution (Damsholt 2002) occurring sporadically, although may be rather common locally than it is expected (due to numerous misidentifications for $\mathrm{R}$. fluitans). It is reported from several countries in Europe: Belgium, Britain, Czech Republic, Denmark, Finland, France, Germany, Hungary, Ireland, Luxembourg, the Netherlands, Poland, Portugal, Slovak Republic, Sweden, Switzerland, Ukraine (Söderström et al. 2002), Romania (Ellis et al. 2011) and central part of European Russia: Republic of Karelia (Potemkin \& Kotkova 2008), Leningrad Province (Potemkin \& al. 2008), Vladimir Province (Borovichev et al. 2012), Tver Province (Potemkin \& Notov 2010), Nizhniy Novgorod Province (Borovichev \& Schestakova 2011), Novgorod Province (Potemkin 2011), Republic of Tatarstan (Andrejeva 2009) and Ural: Bashkortostan Republic (Potemkin \& Baisheva 2010). In Northern America it is known in the East from North Carolina to Georgia, westward to Michigan, Missouri and Texas (Schuster 1992). In Asia the species is known from Turkey (Kiremit \& Kirmaci 2012), Japan (Ellis et al. 2016) and Russian Siberia (Mamontov 2007, Taran et al. 2006, Sofronova 2007, Potemkin \& Volobaev 
2008). This is the first report of Riccia rhenana in the Russian Far East (Fig. 7).

Specimens examined from area treated: RUSSIA. *Primorsky Territory, Khanka District, neighborhood of Il'inka Settlement, Komissarovka River, 44³4'59.4"N $132^{\circ} 04^{\prime} 21.0^{\prime \prime E}$, bank of the river, wet clayey on slope, in loosely interwoven patches and in loose rosettes, 8.XI.2014, E.A. Borovichev \& V.A. Bakalin \#BB1-14 (KPABG; VBGI); Chernigovskij District, neighborhood of Vadimovka Settlement, bank of Ilistaya River, 44 $55^{\prime} 12.3^{\prime \prime N}$ $131^{\circ} 57^{\prime} 55,5^{\prime \prime E}$, wet clayey soil, in loosely interwoven patches, 8.XI.2014, E.A. Borovichev \& V.A. Bakalin \#BB3-14 (KPABG; VBGI).

Other specimens examined: RUSSIA. IRKUTSK PROVINCE, Khyngarcha River Valley, with Ricciocarpos natans, 15.VII.1926, V. Smirnova (KPABG; VBGI; as R. fuitans); Tyumen' Province, Uvatskij District, neighborhood of the Missiya Settlement, bottomland of the Irtysh River, 26.VII.2004, G.S. Taran (KPABG; VBGI); Tyva RepubLIC, Todzhinskaya Kotlovina, bank of the Azas Lake, 14.VII.1999, V.A. Bakalin (KPABG; VBGI; det. V.A. Bakalin); Chita Province, Khentey-Chikoyskoye Nagorye, Kyra District, neighborhood of the Kyra Settlement, bottomland of the Kyra River, 17.VIII.2011, Yu.S. Mamontov (KPABG; VLA); REPUBLIC OF KOREA, JEJU-DO, Seogwipo-si, Saekdal-dong, Wetland, 25.VIII.2010, S.S. Choi (VBGI; Hepaticae Korea Exsiccatae, Fasc. I., \#70); JAPAN. Niigata Prefecture, Tsubame-shi, Watabe, on soil, 21.VIII.2015, T. Yamaguchi \#35652 (HIRO 1029658); IвARAKI Prefecture, Joshu-shi, Higashi Mati, Fukuoka, near Toshuko Bridge, on soil, in pure mats, 13.XII.2007, Q.A. Latiff \#5 (HIRO 247231).

\section{Subgenus Riccia}

Plants usually in complete to incomplete rosettes; thalli small to medium-sized, with deep or shallow furrow; margins and thallus upper surface often with cilia or papillae. Assimilation tissue compact; air-chambers always open, narrow, erect, closely juxtaposed, divided by unistratose lamina; one-two upper rows of laminar cells are called as epidermis (that is not identical to epidermis in subg. Ricciella); ventral tissue relatively thick. Ventral scales vestigial to distinct; in two lateral rows. Monoicous. Sporangia immersed to thallus and not protruding in ventral side; spores exit through dorsal surface of the thallus; sometimes still united in tetrads at maturity; usually alveolate, with spines at the corners of the alveoli.

Type: Riccia glauca L., Sp. Pl. 1139. 1753

A subgenus that includes ca. 110 species (Söderström et al. 2016); six of them are known in the Russian Far East.

Riccia beyrichiana Hampe ex Lehm., Nov. Stirp. Pug. 7: 1. 1838. - R. glaucescens Carrington, Grevillea 8(46): 41. 1878. - R. Lescuriana Austin, Proc. Acad. Nat. Sci. Philadelphia 21: 232. 1869 [1870] - R. lesquereuxii Lindb., Helsingfors Dagblad 1874: 289. 1874. - R. levieri Schiffn., Verh. K.K. Zool.Bot. Ges. Wien 56: 271. 1906.

Description (Fig. 8: 1-4): Plants in incomplete rosettes. Thalli small to medium-sized, (1.5-)2-3 mm wide,
8-12 mm long; 2-4-times furcate; ultimate branches oblong to shortly lingulate or linear obovate; color of upper surface glistening, pale to grayish green, with purple to violet secondary pigmentation; in older parts becoming whitish to yellowish brown; apex thick; rounded-retuse; median furrow deep and narrow at apex, becoming wider almost immediately below apex and then going as furrow with flat or slightly convex bottom, at least $1 / 3$ of the thallus width, delimited laterally by the raised and slightly convex margins, vanishing at base of branches; upper surface flat; thallus margins often enrolled when dry. Cilia scarce to numerous, developed near margins; thin-walled; up to 180-220 $\mu \mathrm{m}$ long; straight or incurved. Dorsal epidermis in 1-2 cell strata; cells rounded to hemispherical-ellipsoidal, with soon disappearing upper half and looks as thick-walled cups (only basal part is preserved); 30-40×52-60 $\mu \mathrm{m}$. Cross-section (2.5-)3-3.5(-4) times wider than thick; furrowed; passing gradually into the obtuse or rounded, rather thick, slightly recurved margin; assimilation tissue high; $1 / 3-1 / 2$ the thallus thickness in the middle; $220-410 \mu \mathrm{m}$ thick, composed by vertically oriented unistratose lamellae of 4-6 cells high, with narrow vertical air-chambers between and ending 1-2 epidermal cells; ventral tissue parenchymatous, consisting of thin- to moderately thick-walled cells; $1 / 2-2 / 3$ the thallus height in the middle. Ventral surface slightly convex; green to merely purplish; thallus branches midrib 550-750(-920) $\mu \mathrm{m}$ thick in cross-section; \pm relatively poor defined. Rhizoids smooth and pegged, hyaline. Ventral scales never projecting; hyaline to purplish; inconspicuous or vestigial. Monoicous. Antheridia scarce, developed along thallus midline; necks hyaline, not prominent; up to $100-160 \mu \mathrm{m}$. Archegonia along middle, necks dark. Sporangia numerous, open dorsally, slightly bulged or projecting like domes; surface over sporangia sometimes purplish; spores disperse by the collapse of thallus. Spores (75-)90-105 $\mu \mathrm{m}$ in diameter; angular-tetrahedral; light- to dark brown; distal face alveolate, with (6-)7-10 alveoli across the face, each 10-16 $\mu \mathrm{m}$ wide; lamellae rather thin to slightly thickened, with tubercles at the corners; proximal surface smooth or shallowly and indistinctly alveolate or irregularly lamellate; with a distinct trilete scar; wing distinct; narrow, thick; 3-8 $\mu \mathrm{m}$ wide; wing margin granular and crenulate; yellowish.

Differentiation. In the field, Riccia beyrichiana may be mistaken with $\mathrm{R}$. bifurca. The main differences are the following: 1) wider thalli, (1.8-)2-3 mm wide, vs. thalli (0.8-) $1-1.3(-1.8) \mathrm{mm}$ wide in $\mathrm{R}$. bifurca; 2 ) cilia often scarce to numerous near margins vs. cilia absent in R. bifurca; 3) larger spores (75-) $90-105 \mu \mathrm{m}$ in diameter, vs. smaller spores (65-)70-90(-102) $\mu \mathrm{m}$ in R. bifurca; 4) wider alveoli in distal spore surface, $10-16 \mu \mathrm{m}$ wide, vs. smaller $9-13 \mu \mathrm{m}$ wide in R. bifurca.

Ecology. Unlike to the most of other Riccia in area treated this species was found in rather dry Quercus forest on south-facing slope, where it was confined to fine soil of neutral reaction in shaded and mesic to slightly moist cliff crevices.

Distribution. Riccia beyrichiana has temperate subcircumpolar distribution and known from Europe and Africa 


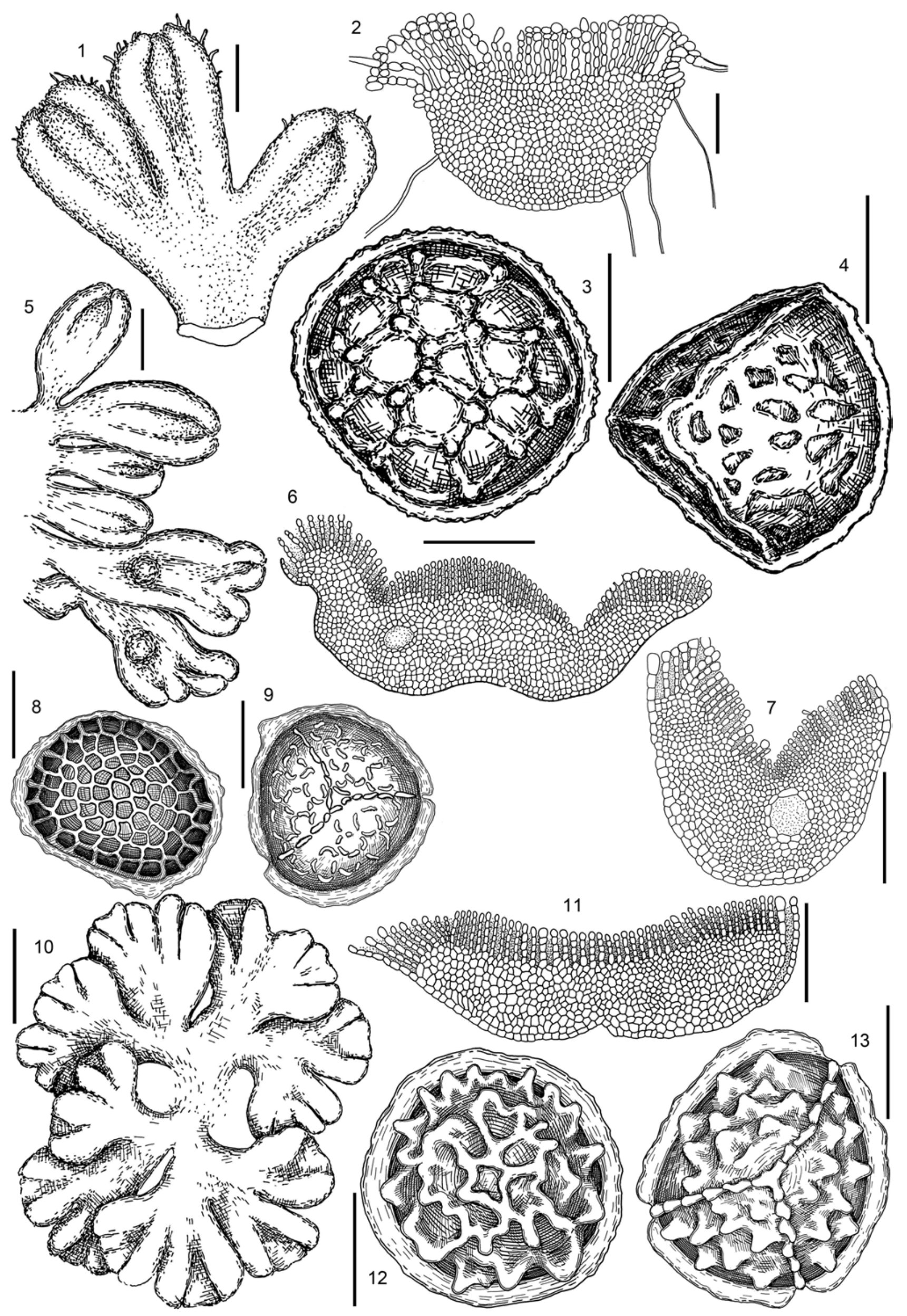


occurring mostly in the countries around the western half of the Mediterranean Sea and in Northern Europe (to Fennoscandia); in North Atlantic it is also known from Iceland, Azores and Greenland (Müller 1952, Arnell 1956, Schuster 1992, Damsholt 2002, Paton 1999, Söderström et al. 2002, Schumacker \& Váňa 2005, Andrejeva 2012, Damsholt 2013, Kiremit et al. 2016). In North America transcontinental, everywhere sporadic, in the west from British Columbia to California, in the east from Massachusetts to Florida, westwards to Minnesota, Texas and Arizona (Schuster 1992). Earlier the species was known in Asia from Altay Territory of Russia (Taran \& Bakalin 2008) and Japan (Tominaga \& Furuki 2014) only. This is the first report of Riccia beyrichiana in the Russian Far East (Fig. 7).

Specimens examined from area treated: RUSSIA. *Primorsky Territory, Khasan Territory, Kedrovaya Pad' State Reserve, south-facing slope of knoll near central scientific station, $43^{\circ} 05^{\prime} 51^{\prime \prime} \mathrm{N} 131^{\circ} 33^{\prime} 31^{\prime \prime} \mathrm{E}, 50 \mathrm{~m}$ alt., broadleaved forest with Quercus dentata dominancy, shaded cliffs, with sporogonia, with Riccia bifurca, 16.IX.2011, Bakalin \#P4-4-07 (VBGI).

Riccia bifurca Hoffm., Deutschl. Fl. 95. 1795. - R. arvensis Austin, Proc. Acad. Nat. Sci. Philadelphia 21: 232. 1869 [1870]. - R. minutissima Steph., Bull. Herb. Boissier 6: 338. 1898. - R. subcrispula Warnst., Kryptogamenfl. Brandenburg 1: 76. 1902 [1903]. - R. japonica Steph., Bull. Herb. Boissier 5: 106. 1897. - R. glauca L. var. japonica (Steph.) S. Hatt., J. Hattori Bot. Lab. 5: 92. 1951.

Description (Fig. 8: 5-9): Plants in incomplete rosettes, distanced one from another. Thalli small to medium-sized, (0.8-)1-1.3(-1.8) mm wide, 3-8 mm long; 2-4-times furcate; ultimate branches ovate or oblong to linear obovate; upper surface light to grayish green, with purple to reddish secondary pigmentation; in older parts becoming whitish to yellowish brown; apex thick; rounded; retuse to truncate; median furrow narrow at apex, become wider almost immediately below apex and going as narrow or broad channel with flat bottom, occupying at least $1 / 3$ of the thallus width, with raised and slightly convex margins, disappear to the base of branches; upper surface flat; thallus margins green to purplish; slightly enrolled when dry. Cilia absent or scarce; thin-walled; up to 160-220 $\mu \mathrm{m}$ long. Dorsal epidermis 1-2-stratose; cells rounded to hemispherical-ellipsoidal, with soon destroying upper half; 30-40×42-55 $\mu \mathrm{m}$; with thin- to slightly thickened walls. Cross-section 3-4 times wider than thick; furrowed; assimilation tissue high; $1 / 3-1 / 2$ of the thallus thickness in the middle; $220-410 \mu \mathrm{m}$ thick; composed by vertically oriented unistratose lamellae of 4-6 cells high, with narrow vertical air-chambers between and ending 1-2 epidermal cells; ventral tissue parenchymatous, composed by thin- to moderately thick-walled cells; $1 / 2-2 / 3$ the thallus thickness in the middle. Ventral surface slightly convex; more or less purplish or green; thallus midrib $350-580 \mu \mathrm{m}$ thick in cross-section; \pm relatively poorly defined. Rhizoids smooth and pegged, hyaline. Ventral scales never projecting; hyaline or purplish to violet; inconspicuous. Monoicous. Antheridia scarce, conspicuous near apex of thallus; necks hyaline; up to $160 \mu \mathrm{m}$. Archegonia below apex, necks dark. Sporangia numerous dorsally; mature sporophytes projecting like domes; surface over sporangia sometimes purplish; spores exit by hole in dorsal surface. Spores (55-)70-80(-88) $\mu \mathrm{m}$ in diameter; tetrahedral; light- to dark yellowish to brown; distal surface alveolate, with 5-8 alveoli across the face, each 8-10 $\mu \mathrm{m}$ wide; lamellae rather thin or locally thickened, with short tubercles at the corners; proximal surface smooth or shallowly and indistinctly alveolate; with distinct trilete scar; wing distinct; narrow, slightly thickened, 3-5 $\mu \mathrm{m}$ wide; wing margin irregularly crenulate; yellowish.

Differentiation. R. bifurca may be mistaken with R. glauca when the latter produce 'narrow thallus modifications'. Besides both taxa may grow intermixed. The main differences are the following: 1) thicker thallus cross-section: 3-4 times wider than thick in R. bifurca vs. 4-5.5 times even in 'narrow thallus modifications' of R. glauca; 2) ventral scales are often purplish vs. totally hyaline in $\mathrm{R}$. glauca. R. japonica Steph. mentioned in the synonymy above, may belong to separate taxon although morphologically related to R. bifur$c a$, but this question needs further studies including also molecular-genetic and type explorations.

Ecology. This species occurs in the southern extreme of the Russian Far East (southern half of Primorsky Territory) where it is confined to fine soil in open or partly shaded cliffs commonly surrounded by temperate Quercus forest. The most of localities are from sea coastal cliffs and a few remained are from the distance not more than $20 \mathrm{~km}$ away of sea coast. The distribution of R. bifurca in Kamchatka is quite another matter, dissimilar to its distribution patterns in other part of the area. It was collected in geothermal field with extensive hot springs in the southern part of East Kamchatka, on the ground heated with highly mineralized thermal water. This is the only locality for the species in northern part of the Russian Far East and is distant form other known localities of the species for ca. $2000 \mathrm{~km}$ northward. The habitat is somewhat similar to that in Kireunskiye Hot Springs (Central Kamchatka) where R. buebeneriana was collected.

Distribution. Riccia bifurca has temperate circumpolar distribution and known from Europe, Asia, Northern Africa, Australia and New Zeland, Northern America (Schuster 1992, Damsholt 2002, Andrejeva 2012, Tominaga \& Furuki 2014). In the Russian Far East the species was before reported from the single locality in Chukotka Autonomous District (Afonina \& Duda 1993) and also in Primorsky Territory (Andrejeva 2009). In the course of our studies, it has been confirmed from Primorsky Territory and Kamchatka

Figure 8 Riccia beyrichiana Hampe ex Lehm. (1-4): all from Primorsky Territory, Bakalin \#P4-4-07 (VBGI). 1 - habit of plant, dorsal view; 2 - thallus transverse section; 3 - spore, distal face; 4 - spore, proximal face. Scale bars: $1 \mathrm{~mm}$ for $1 ; 300 \mu \mathrm{m}$ for $2 ; 50 \mu \mathrm{m}$ for $3-4 ;$ Riccia bifurca Hoffm. (5-9): all from Primorsky Territory, Bakalin \#P83-20-07 (VBGI). 5 - habit of plant, dorsal view; 6-7 - thallus transverse section; 8 - spore, distal face; 9 - spore, proximal face. Scale bars: $1 \mathrm{~mm}$ for 5; $300 \mu \mathrm{m}$ for 6-7; $30 \mu \mathrm{m}$ for 8-9; Riccia glauca L. (10-13): all from Primorsky Territory, Bakalin \#P74-5-08 (VBGI). 10 - habit of plant, dorsal view; 11 - thallus transverse section; 12 - spore, distal face; 13 - spore, proximal face. Scale bars: $1 \mathrm{~mm}$ for $10 ; 300 \mu \mathrm{m}$ for $11 ; 30 \mu \mathrm{m}$ for $12-13$ 


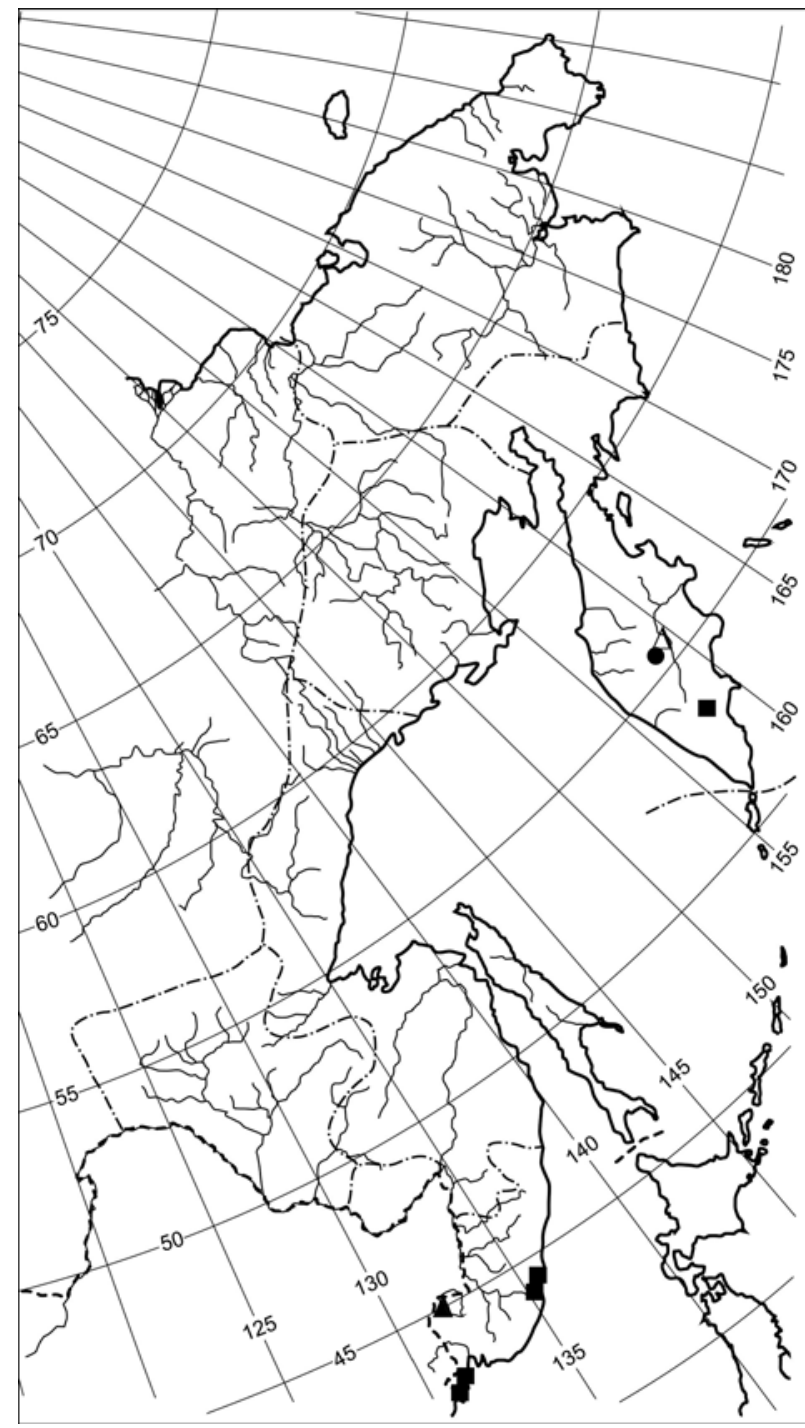

Figure 9 The distribution of Riccia bifurca Hoffm. - squares, Riccia glauca L. - triangles, Riccia lamellosa Raddi - circles (open figures -literature records, filled figures - studied specimens)

Territory. The report of the species from Chukotka is based on misidentification of R. sorocarpa (Fig. 9).

Specimens examined from area treated: RUSSIA. *Kamchatka Territory, Malkinskie Gorychye Kluchi, on volcanic thermal field, on soil,18.III.2016, O.A. Chernyagina (VBGi; KPABG); Primorsky Territory, Ol'ginskiy District, Vatovskogo Peninsula, northern edge of Vladimir Bay near Ol'ga Settlement, fine-grained ground in crevice of coastal cliff, with sporogonia, 21.IX.2007, V.A. Bakalin \#P83-20-07 (VBGI; as Riccia sp.); ibidem, with sporogonia, with R. sorocarpa, 21.IX.2007, V.A. Bakalin \#P83-5-07 (VBGI; as Riccia sp.); Khasan District, Kedrovaya Pad' State Reserve, sout-facing slope of knoll near central scientific station, broadleaved forest with Quercus dentata dominancy, shaded cliffs, with sporogonia, with Riccia beyrichiana, 16.IX.2011, Bakalin \#P4-4-07 (VBGI); Idol Bay, Southern slope of Astaf'ev Mt., on dry fine-grained soil, with sporogonia, with Riccia sorocarpa, 16.X.2004, V.A. Bakalin \#\#1411-04, 141-3-04 (KPABG; as Riccia beyrichiana); ibidem, with sporogonia, 16.X.2004, V.A. Bakalin \#141-2-04 (KPABG; as Riccia beyrichiana); ca. $7 \mathrm{~km}$ southward Ryazanovka Settle- ment, on cliffs near sea, 14.IX.1985, M.S. Ignatov (MHA); Dal'negorsk Town Area, sea shore area ca. $10 \mathrm{~km}$ northward of Rudnaya Pristan Village, Quercus mongolica forest on steep slope to sea, in part shade by Quercus, with sporogonia, 16.IX.2011, Bakalin \#P66-10-11, P66-11-11 (VBGI).

Other specimens examined: RUSSIA, REPUBLIC OF Altay, Kamenskij District Ob' River flood-plane, eastern bank of Nizhnyaya Zalomnaya River, forbs-grass-sedge meadow, on the ground, with sporogonia, 12.VIII.2006, G.S. Taran (VBGI); JAPAN, Hiroshima Prefecture, Akitakata-shi, Takamiya-cho, Bogo, on soil in garden, with sporogonia, 11.X.2004, H. Deguchi (VBGI; KPABG); Kochi Prefecture, Takaoka-gun, Ochi-cho, Ochi-Otsu, Yugyoji, on soil in rice field, 24.I.2008, H. Deguchi \#37889 (HIRO 247477); TOKYO-TO, Shin juku-ku, Nishi-shinjuku, on soil by roadside, 4.XI.2010, A. Uchida in hb. T. Katagiri \#3239 (HIRO \#1009618); Nagasaki Prefecture, Nishisonogi-gun, Ohseto-cho, Matsushima, 7.XII.1974, H. Ando (HIRO); AUSTRALIA, Tasmania, Glen Huon Memorial Park, on soil at edge of path into park, with sporogonia, 15.VIII.2009, R.D. Seppelet \#27982 (ADT; VBGI).

Riccia glauca L., Sp. Pl. 1139. 1753. - R. subinermis Lindb., Meddl. Soc. Fauna Fl. Fennica: 264. 1881. - R. glauca var. subinermis (Lindb.) Warnst., Krypt. Fl. Brandenburg, Leber.\& Torfm. 70. 1902.

Description (Fig. 8: 10-13): Plants in incomplete rosettes or forming diffuse patches. Thalli small to mediumsized, (1-)1.5-2.0 mm wide, 5-10 mm long; 2-4 times furcate; ultimate branches shortly oblong to obovate; color of upper surface pale to yellowish or grayish green, never with reddish tint; in older parts becoming whitish; apex thin; rounded to emarginate; furrow narrow, distinct at apex, but become shallow and disappear downward; upper surface flat to slightly concave, becoming weakly convex with age; thallus margins thin and acute; often enrolled when dry. Cilia absent or sparse; up to $220-250 \mu \mathrm{m}$; erect. Dorsal epidermis in 1-2 strata; cells rounded to hemispherical-ellipsoidal; 35-55(-65) $\mu \mathrm{m}$ wide; thin- to slightly thickened walls and soon collapsing. Cross-section 4-5.5 times wider than thick; semicircular to widely semicircular, furrowed; assimilation tissue high, compact, 150-350 $\mu \mathrm{m}$ thick, composed by vertically oriented unistratose lamellae of 4-6 cells high, with narrow vertical air-chambers between and ending 1 (2) epidermal cells; ventral tissue parenchymatous, cells thinto moderately thick-walled; $1 / 4-1 / 3$ of the thallus thickness in the middle. Ventral surface slightly convex; pale green to hyaline; thallus branch midrib fleshy; $300-540 \mu \mathrm{m}$ thick in cross-section; \pm relatively poorly defined. Rhizoids smooth and pegged, hyaline, sparse. Ventral scales never projecting beyond the margin; ephemeral; easily deciduous, hyaline. Monoicous. Antheridia scarce, situated in the centre of thallus; necks hyaline, not prominent; up to $90-150 \mu \mathrm{m}$ in diameter. Archegonia along midline, necks purple to dark. Sporangia numerous, dorsal, in a row along furrow; dorsal surface over mature sporophytes flat or slightly bulged; spores disperse by collapsing of thallus. Spores (55-)70(80) $\mu \mathrm{m}$ in diameter; tetrahedral; reddish- to dark-brown; distal surface alveolate, with 7-10 alveoli across the face, each 6-10 $\mu \mathrm{m}$ wide; lamellae rather thin, with papillae or short 
tubercles at the corners; proximal face similar to distal face, but with smaller alveoli and tubercles to indistinctly alveolate; with indistinct trilete scar; wing distinct; wide, thin, 3-6(-7) $\mu \mathrm{m}$ wide; wing margin almost entire; yellowish.

Differentiation. Riccia glauca may be easily mistaken with $R$. sorocarpa. The main differences are the following: 1) wider thalli (1.5-2 mm), vs. thalli $0.5-1 \mathrm{~mm}$ wide in $R$. sorocarpa; 2) cross-section 4-5.5 times wider than thick, vs. 2-3 times in R. sorocarpa; 3) median furrow distinct at apex, but immediately become shallow and disappear downward, vs. furrow distinct at apex and continuing along the most of the thallus length in R. sorocarpa; 4) spores of R. glauca less spinose-tuberculate vs. more spinose-tuberculate in $R$. sorocarpa. Aside R. sorocarpa the confusion is likely possible with $R$. beyrichiana. Both species share very wide thallus cross section and distinct at apex, but disappearing below median furrow. R. glauca differs from $R$. beyrichiana in: 1) smaller spores (55-)70(-80) $\mu \mathrm{m}$ in diameter, vs. (75-)90-105 $\mu \mathrm{m}$ in R. beyrichiana; 2) narrower alveoli $6-10 \mu \mathrm{m}$ wide vs. $10-$ $16 \mu \mathrm{m}$ in $\mathrm{R}$. beyrichiana; 3$)$ narrower thalli $(1.5-2 \mathrm{~mm})$ vs. thalli 2-3 mm wide in $R$. beyrichiana.

Ecology. Like other part of East Asia this species is the typical colonizer of clayey soil in arable fields (including rice fields), where is common at edges, although sometimes going far inward. The species prefers open areas and soils with neutral reaction. The locality in Kamchatka Territory is cited as clayey riverbank (Bakalin 2009), but we assume the latter record belongs to $R$. frostii or $R$. huebeneriana. The specimen seems to be was lost and could not be revised in present study.

Distribution. Riccia glauca is "imperfectly Holarctic" (Schuster 1992: 631) with the most of localities from the areas adjacent to Altantic or Pacific Ocean, with rather disjunctive occurrence in New Zealand (Schuster 1992, Damsholt 2002, Tominaga \& Furuki 2014). In Russia, the species was recorded for European part, Southern Ural, Siberia and Far East (Konstantinova, Bakalin et al. 2009). Previously R. glauca was reported from Chukotka Autonomous District (Afonina \& Duda 1993), Kamchatka (Bakalin 2009), Khabarovsk (Lindberg 1872) and Primorsky (Bakalin 2008) Territories. However, the cited specimen from Chukotka Autonomous District (Afonina \& Duda 1993) belongs to R. sorocarpa (Fig. 9).

Specimens examined from area treated: RUSSIA. Primorsky Territory, Khanka District, ca. $7 \mathrm{~km} \mathrm{~N}$ of Novokachalinsk, edge of arable field, on soil, 18.X.2008, V.A. Bakalin \#P74-5-08 (VBGI; KPABG).

Other specimens examined: CHINA, Guizhou ProvINCE, Kaijang County, Xiang Zhi Stream, agricultural land in country side, clay in the rice field margin, in open place, with sporogonia, 20.XI.2013, V.A. Bakalin \#China54-1-13 (VBGI; KPABG).

Riccia lamellosa Raddi, Opusc. Sci. 2 (6): 351. 1818. - Riccia lamellosa var. americana M. Howe, Bull. Torrey Bot. Club 25: 189. 1898. - Riccia americana M. Howe, Mem. Torrey Bot. Club 7: 24, pl. 90. 1899.

Description (Illustrations may be found in Schuster (1992: p. 436, fig. 988 (10-15), p. 539, fig. 1004; p. 541, fig. 1005); Ladyzhenskaja (1961: p. 254, fig. 2; p.255, fig. 3; Fu- ruki (2000: p. 314, fig. 1).): Plants forming diffuse patches. Thalli small to medium-sized, $1.6-3 \mathrm{~mm}$ wide, $4-8 \mathrm{~mm}$ long; 1-3-times furcate; ultimate branches lingulate to obovate; upper surface light to grayish green to discolored, without purple or reddish secondary pigmentation, in older parts becoming whitish to yellowish; apex thick; rounded or rounded-emarginate; median furrow sharp, deeply impressed distally and becoming soon shallow; upper surface flat to slightly convex; thallus margins with narrow, hardly distinct lateral wings, acute. Cilia absent. Dorsal epidermis 2-stratose; uppermost cells rounded, with soon destroying upper half; 32-50×34-55 $\mu \mathrm{m}$; thin-walled. Cross-section 2-3 times wider than thick; furrowed; assimilation tissue compact; $1 / 3-1 / 2$ of the thallus thickness in the middle; 200-520 $\mu \mathrm{m}$ thick; composed by vertically oriented unistratose lamellae, with narrow vertical air-chambers between and ended by 2 epidermal cells; ventral tissue massive; $1 / 2-2 / 3$ the thallus thickness in the middle. Ventral surface slightly convex; green to hyaline; thallus midrib 250 $780 \mu \mathrm{m}$ thick in cross-section; \pm relatively poorly defined. Rhizoids smooth and pegged, hyaline. Ventral scales hyaline, never purplish or violet; ovate to semilunar, large, imbricate, mostly going beyond thallus margin and then forming whitish 'rim'. Monoicous. Antheridia scarce, conspicuous near median furrow; almost not elevated. Sporangia numerous dorsally; mature sporophytes slightly projecting like domes; spores exit by hole in dorsal surface. Spores 80-100(-110) $\mu \mathrm{m}$ in diameter; dark brown; distal surface with regular and usually completely apical alveoli, with 5-6(-7) alveoli across the face, each 12-18(-24) $\mu \mathrm{m}$ wide; with papillae or short tubercles at the corners; proximal surface smooth or shallowly and indistinctly areolate; with distinct trilete scar; wing lacking or narrow, 3-5 $\mu \mathrm{m}$ wide.

Differentiation. The species may be easily identified due to large, imbricate ventral scales going beyond thallus margin and may be hardly confused with other taxa in area treated. Our specimens characterized by larger thallus epidermal cells $32-50 \times 34-55 \mu \mathrm{m}$ and spores with 5-6(-7) alveoli across the distal face, each 12-18(-24) $\mu \mathrm{m}$ wide. The specimens from Japan and the Russian Far East are very similar between each other, but slightly different from plants in other part of the specific area. Taxonomic status of these Kamchatka-Japanese populations require further studies.

Distribution. Riccia lamellosa has very wide distribution, and is known in Mediterranean Europe, Northern and Central Africa, southern area of North America as well as temperate and subtropical part of South America and Asia (Ladyzhenskaja 1961, Schuster 1992, Söderström et al. 2002, Furuki 2000, Kiremit \& Kirmaci 2012) (Fig. 9).

Ecology. In the most extent of the area this is the species of drying up ponds and fine earth in steppoid communities in steep slopes. This is somewhat similar to that where this species was recorded in the central part of Kamchatka Peninsula (Bakalin 2009). The species was found within subarctic zone, in rather open crevices of steep cliffy wall of riverside terrace.

Specimens examined from area treated: RUSSIA. Kamchatka Territory, Central Kamchatka, Esso Settl. 


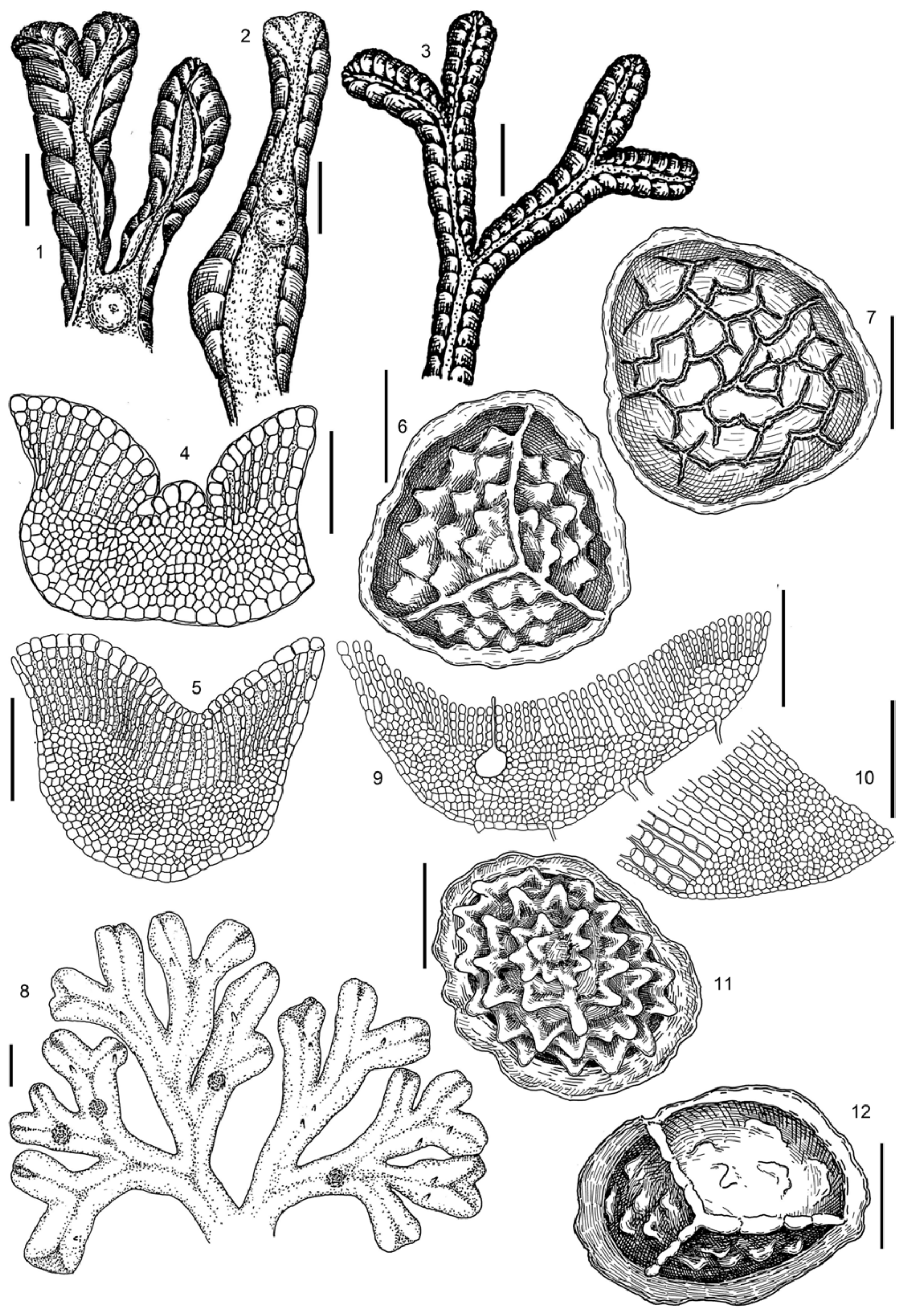


Area, Agtam Stream Basin, 56 $02.685^{\prime} \mathrm{N}, 158^{\circ} 44.769^{\prime} \mathrm{E}$, $793 \mathrm{~m}$ alt., subalpine belt, slope to stream valley with many rocky outcrops, on bare soil under hanging tussock in upper part of tufa rocks, 5.IX.2001, V.A. Bakalin 91-3-01 (KPABG); ibidem, with sporogonia, in diffuse patches 5.IX.2001, V.A. Bakalin 91-2-01 (KPABG), 16.VII.2016, K.G. Klimova Kam-51-33-16 (VBGI; KPABG).

Other specimens examined: JAPAN, KANAGAWA Prefecture, Miura-shi, soil, along road, 22.XI.2002, T. Furuki \#171671 (TNS); Kamakure-shi, near Kencho-si Temple, at open place, on soil, 6.IX.2001, T. Furuki \#171582 (TNS); Tokio, Oshima-cho, Iru Island, 25.II.2005, M. Higuchi \#137870 (TNS); ibidem, Okata, in garden, on soil, 25.II.2005, T. Furuki \#175661 (TNS).

Riccia nigrella DC., Fl. Franç. (ed. 3) 6: 193. 1815.

Description (Fig. 10: 1-7): Plants in complete to incomplete rosettes. Thalli of strongly xeric habit; very small to medium-sized, 0.5-1.0(-1.3) $\mathrm{mm}$ wide, 3-6 $\mathrm{mm}$ long; simple or 1-4-times furcate, narrowly to moderately divergent; ultimate branches linear-ovate or oval to narrowly oblong; color of upper surface dark green, along margins and toward base dark violet; apex obtuse to subacute, sometimes emarginate; median furrow narrow and deep along whole length of branches; upper surface canaliculate; glossy; reticulate; thallus margins acute, slightly recurved, becoming somewhat obtuse toward thallus base; slightly to strongly enrolled, tubular and black in dry conditions. Dorsal epidermis unistratose; long-persistent; hyaline; cells rounded to subquadrate, $25-35 \times 25-32 \mu \mathrm{m}$; thin- to medium thick-walled. Cilia absent. Cross-section as wide as thick to 2-times wider than thick; semicircular to wide semicircular, strongly furrowed; without lateral hairs; assimilation tissue high, compact, 260-310 $\mu \mathrm{m}$ thick; composed by vertically oriented unistratose lamellae of $6-10$ cells high, with narrow vertical air-chambers between and ending 1-2 epidermal cells; ventral tissue parenchymatous, consisting of thin-walled cells; $1 / 2$ of the thallus thickness in the middle. Ventral surface convex; green, with often brown or purple tints; covered by shiny black scales; thallus branches midrib \pm relatively well-defined; 500-600 $\mu \mathrm{m}$ thick in cross-section or thinner in older parts. Ventral scales extending to margin and slightly beyond it at branch apex; semicrescentic, imbricate; shiny, strongly dark purple to violet-black; medium-sized, 450-500×(200-)400$450 \mu \mathrm{m}$; scale body cells $45-50 \times 22-25 \mu \mathrm{m}$; marginal cells discolored. Monoicous. Antheridia along thallus midline, in furrow bottom; neck hyaline. Archegonia along thallus midline, necks purple. Sporangia open dorsally; before opening sporophytes projecting like domes dorsally. Spores (60-)65-75 $\mu \mathrm{m}$ in diameter; angular-tetrahedral; dark brown with red tint; distal face alveolate, with 7-9 incomplete alveoli across the face or with irregular, thick lamellae; proximal face with a trilete scar, its arms generally wider at juncture with wing, about numerous small are-

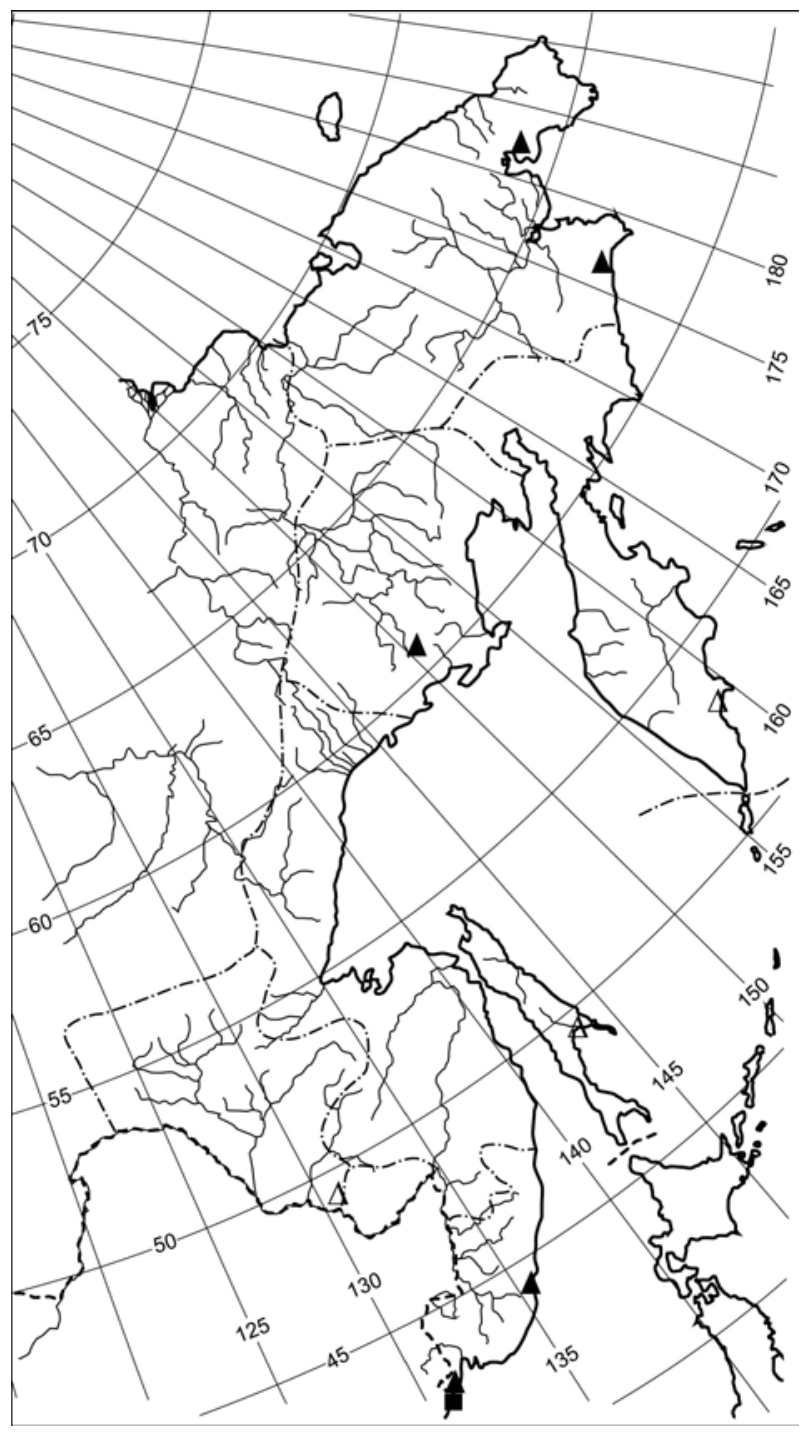

Figure 11 The distribution of Riccia nigrella DC. - squares, Riccia sorocarpa Bisch. - triangles (open figures - literature records, filled figures - studied specimens)

olae on each 3 facets, lamellae thick, slightly raised at nodes; wing narrow, 2.5-5 $\mu \mathrm{m}$ wide; granular to smooth; notched or perforated at angles; wing margin finely crenulate.

Differentiation. Riccia nigrella can be easily distinguished from other Russian species by its large, shiny dark purple to violet-black ventral scales and noticeably small size. As the plants dry out, their margins become strongly incurved and enrolled so the scales are easily visible from dorsal view.

Ecology. The species was found over fine soil covering open stones near coastal cliff base, where it was intermixed with Targionia bypophylla.

Distribution. The area of the species covers Europe - southern regions (Spain, Portugal (including Azores, Madeira and Canary Islands), Italy (including Sardinia and Sicily), Greece, Serbia, Switzerland, France (Söderström et al.

Figure 10 Riccia nigrella DC. (1-7): all from Primorsky Territory, 9.VIII.1986, Gambaryan (VBGI). 1-3- habit of plant, dorsal view; 4-5 - thallus transverse section; 6 - spore, proximal face; 7 - spore, distal face. Scale bars: $0.5 \mathrm{~mm}$ for $1-3$; $400 \mu \mathrm{m}$ for $4-5$; 30 $\mu \mathrm{m}$ for $6-7$; Riccia sorocarpa Bisch. (8-12): all from Magadan Province, Bakalin \#Mag56-5-11 (VBGI). 8 - habit of plant, dorsal view; 9 - thallus transverse section; 10 - part of thallus transverse section; 11 - spore, distal face; 12 - spore, proximal face. Scale bars: $0.5 \mathrm{~mm}$ for 8 ; $400 \mu \mathrm{m}$ for $9-10 ; 30 \mu \mathrm{m}$ for $11-12$ 
2002, Schumacker \& Váňa 2005) and northward it spreads to Great Britain only (Paton 1999); northern Africa (Perold 1999); North America (Schuster 1992) as well as Australia (Scott 1985). In Asia, the species has been reported from Israel (Jovet-Ast \& Bischler 1966), southern-west China (Piippo 1990) and Japan (Katagiri \& Furuki 2012). This is the first report of Riccia nigrella for Russia that noticeable extends the understanding of distribution of the taxon (Fig. 11).

Type specimen examined: FRANCE, HÉrAUlT, D. Bouchet, s.n. (G 00052609, isotype).

Specimens examined from area treated: RUSSIA. * Primorsky Territory, Khasan District, $2 \mathrm{~km}$ from Nerpa Bay, Kruglaya Bay, near base of coastal cliffs, on wet stones covered by fine soil, with Targionia bypophylla, 9.VIII.1986, S.K. Gambaryan (VBGI).

Other specimens examined: JAPAN, Hiroshima PREFECTURE, Akitakata-shi, Takamiya-cho, Bogo, on soil in garden, 11.X.2004, H. Deguchi (VBGI; KPABG).

Riccia sorocarpa Bisch., Nov. Actorum Acad. Caes. Leop.Carol. German. Nat. Cur. 17: 1053. 1835.

Description (Fig. 10: 8-12): Plants grey-green to bluish green; in incomplete rosettes or forming diffuse patches. Thalli small to medium-sized, 0.5-1.0 mm wide, 3-6(8) mm long; (1-)2-4-times furcated; ultimate branches oblong-ovate to linear; color of upper surface light green, never with reddish spots; in older parts becomes yellowish; apex merely narrow, thick, subacute to rounded; median furrow distinct along the most of thallus length; upper surface reticulate, often papillose; slightly concave; papillae scattered at margins and upper part of thallus; conical; hyaline; thin-walled, about 80-120 $\mu \mathrm{m}$ long, often slightly curved; thallus margins narrow; hyaline; slightly enrolled when dry. Cilia absent. Dorsal epidermis 1-2-stratose; cells spherical or ovoid to pyriform, with destroyed upper half; $(30-) 35-40(-45) \times 22-25(-29) \mu \mathrm{m}$; with thin- to slightly thickened walls. Cross-section semicircular to widely semicircular, slightly furrowed; 2-3-times wider than thick; assimilation tissue high, compact, $150-250 \mu \mathrm{m}$ thick; $1 / 3-2 / 5$ the thallus thickness in the middle; composed by vertically oriented unistratose lamellae of $4-5$ cells high, with narrow vertical air-chambers between and ending 1-2 epidermal cells; ventral tissue parenchymatous, consisting of thinwalled cells; 3/5-2/3 the thallus thickness in the middle. Ventral surface slightly convex; green to occasionally violet or purple; thallus midrib fleshy, 340-600 $\mu \mathrm{m}$ thick in cross-section; \pm relatively well-defined. Rhizoids smooth and pegged, hyaline, covering ventral surface of midrib of the thallus. Ventral scales overlapping branch apex; hyaline or often pale violet; fragile; semicrescentic; small, (390) $410-430 \times 200-250 \mu \mathrm{m}$; scale body cells $45-65(-70) \times(25-$ )35-40 $\mu \mathrm{m}$. Monoicous. Antheridia in rows along thallus midline, necks hyaline, not prominent. Archegonia distributed along midline; with purple necks. Sporangia numerous, dorsally protruding. Spores (55-)75-80 $\mu \mathrm{m}$ in diameter; tetrahedrical-globular; brown to dark reddish brown, glistening; distal surface alveolate, with 5-8(-10) alveoli across the face, each $8-10 \mu \mathrm{m}$ in diameter; lamellae thin, with tubercles at the corners of the alveoli; proximal face granular, punctate, usually indistinctly alveolate, often with a trilete scar; wing narrow or indistinct; $2-3(-4) \mu \mathrm{m}$ wide; wing margin irregularly crenulate.

Differentiation and variation. Differences from morphologically similar Riccia glauca were discussed above. R. sorocarpa is easily recognized species due to narrow, persistent median furrow flanked by acute hyaline margins which are visible with a hand lens. $R$. sorocarpa includes two subspecies: subsp. sorocarpa and subsp. arctica R.M. Schust. The latter differs from the former (Schuster 1992) in: smaller spores 65-86(-91) $\mu \mathrm{m}$ vs. (70-)75-98(-108) $\mu \mathrm{m}$ in subsp. sorocarpa; smaller alveoli $5-8(-10) \mu \mathrm{m}$ in diameter vs. 7-12(14) $\mu \mathrm{m}$ in subsp. sorocarpa; almost lacking of spore wing vs. narrow, 3-6 $\mu \mathrm{m}$ wide wing. Specimens of Riccia sorocarpa from subarctic condition in Magadan Province and arctic condition in Chukotka Autonomous District are similar to subsp. sorocarpa (although it was difficult to expect) in spore morphology, and ssp. arctica does not occur in the Russian Far East.

Ecology. The species shows the great habitat variability occurring mostly in mesic to xeric conditions. It occupies fine soil in open to partly shaded cliff crevices near sea coast in Temperate zone at the southern flank of the area treated. Northward, in Subarctic, it grows in moist (but frequently dried out) fine soil in solifluction spots in alpine tundra (Kolyma Upland) or occurs in lower elevations in geothermal habitat (grass-moss community near thermal pool in Koryak Upland).

Distribution. Riccia sorocarpa is subcosmopolitan species (Paton 1999), known from Europe, Asia, Northern Africa, Northern America, and also disjunctive in Australia and South America (Na-Thalang 1980, Schuster 1992, Damsholt 2002, Paton 1999, Katagiri \& Furuki 2012). In the Russian Far East, R. sorocarpa was recorded for Chukotka Autonomous District, Amur and Sakhalin Provinces and Kamchatka and Primorsky Territory (Andrejeva 2009, Bakalin 2010). In the course of our study, it has been also found in Magadan Province (Fig. 11).

Specimens examined from area treated: RUSSIA. Chukotka Autonomous District, Pekul'ney Lake, at the bottom of the desiccated lake, with sporogonia, 5.VIII.1984, O.M. Afonina (LE, VBGI); Tel 'menskie hot springs, grassy-moss communities near the hot springs, 18.VII.1979, O.M. Afonina (LE, KPABG); ibidem, moss communities near the hot springs, with sporogonia, 24.VII.1977, O.M. Afonina (LE, KPABG); *Magadan ProVINCE, Ol'skoe Basalt Plateau in upper course of Olya River, $60^{\circ} 38^{\prime} 47^{\prime \prime N} 151^{\circ} 13^{\prime} 56^{\prime \prime E}, 1262 \mathrm{~m}$ alt., flat mountainous plateau, covered by wet tundra, solifluction spots, fine-grained soil, with Fossombronia alaskana Steere \& Inoue, 10.VIII.2011, V.A. Bakalin \#Mag56-5-11 (VBGI; KPABG); ibidem, area near the top of Skif Mt., N-facing slope, 60 $38^{\prime} 27^{\prime \prime} \mathrm{N}$ $151^{\circ} 22^{\prime} 34^{\prime \prime E}, 1600 \mathrm{~m}$ alt., solifluction spot in tundra, with Mannia gracilis (F.Weber) Schill \& D.G. Long, 7 August 2014, V.A. Bakalin, \#Mag31-24-14 (VBGI); *PRimORSKY Territory, Khasan District, neighborhood of Andreevka Settlement, shaded cliffs near sea, 1.IX.2013, R.V. Dudkin (VBGI; KPABG); Idol Bay, Southern slope of Astaf ev 
Mt., 42³7'10"N $131^{\circ} 08^{\prime} 05^{\prime \prime} \mathrm{E}$, on dry fine-grained soil, with sporogonia, with Riccia bifurca, 16.X.2004, V.A. Bakalin \#\#141-1-04, 141-3-04 (KPABG); ibidem, with sporogonia, with Targionia hypophylla L., 16.X.2004, V.A. Bakalin \#140-2-04 (KPABG), Ol'ginskiy District, Vatovskogo Peninsula, northern edge of Vladimir Bay near Ol'ga Settlement, $43^{\circ} 53^{\prime} 00^{\prime \prime} \mathrm{N}, 131^{\circ} 30^{\prime} 37^{\prime \prime} \mathrm{E}, 25 \mathrm{~m}$ alt., fine-grained ground in crevice of coastal rocks, with sporogonia, with R. bifurca, 21.IX.2007, V.A. Bakalin \#P83-5-07 (VBGI).

\section{ACKNOWLEDGEMENTS}

We are deeply indebted to the curators of MHA (Dr. M.S. Ignatov), LE (Dr. A.D. Potemkin) for specimen loans as well as Dr. M. Price (G), TNS (M. Higuchi), HIRO (Dr. T. Yamaguchi), NICH (Dr. M. Mizutani), for providing of necessary facilities during senior author trip to Geneva, Tsukuba, Hiroshima and Obi correspondingly. The line-drawings were kindly prepared by Mr. M.A. Bakalin to whom authors are sincerely grateful. Authors are deeply indebted to Ms. K.G. Klimova and Ms. O.A. Chernyagina for providing some herbarium specimens that considerably improved the distribution patterns of some species in the Russian Far East. We thank two anonymous reviewers for valuable comments and helpful criticism that improved the manuscript. The work was partially supported by the Russian Foundation of Basic Researches (grants no. 15-04-03479, 15-34-20101) and President's Program for support of PhD researches (MK-2926.2015.4).

\section{LITERATURE CITED}

Afonina, O.M. \& J. Duda 1993. Liverworts of Chukotka. Botanicheskii Zhurnal 78(3):77-93 (in Russian). [Афонина О.М., Ауда Й. 1993. Печеночники Чукотки. // Ботанический журнал. Т. 78, № 3. С. 77-93].

Andrejeva, E.N. 2009. New rare liverwort records from Russian Federation regions. Arctoa 18:281-286.

Andrejeva, E.N. 2012. New species and new records of the genus Riccia (Marchantiopsida) for the bryoflora of Ukraine. Chernomorskij Botanicheskij Zhurnal 8(1):49-55 (in Russian). [Андреева Е.Н. Новые виды и новые находки pода Riccia (Marchantiopsida) Аля бриофморы Украины // Черноморский ботанический журнал Т. 8, №. 1. C. 49-55].

Arnell, H.W. 1927. Lebermoose aus Kamtschatka. Hedwigia 67:110-112.

Bakalin, V.A. 2008. On taxonomy of some hepatics from Primorskiy Territory (Russian Far East), with the list of taxa of the territory. Arctoa 17:101-108.

Bakalin, V.A. 2009. Flora and phytogeography of liverworts of Kamchatke and adjacent islands. KMK, Moscow, $367 \mathrm{pp}$. (in Russian). [Бакалин В.А. 2009. ФАора и фитогеография печеночников Камчатки и прилегающих островов. M.: KMK. 367 c.].

Bakalin, V.A. 2010. Distribution of bryophytes in the Russian Far East. P. 1. Hepatics. Izd-vo DVFU, Vladivostok, 175 pp.

Bakalin, V.A., V.Ya. Cherdantseva, M.S. Ignatov, E.A. Ignatova \& T.I. Nyushko 2009. Bryophyte flora of southern Kurils Islands. Arctoa 18:69-114.

Bakalin, V.A., Y. Xiong \& E.A. Borovichev 2015. Additions to the knowledge of Guizhou hepatics (South China). Arctoa 24:509-519.

Berrie, G.K. 1964. Experimental studies on polyploidy in liverworts. I. The Riccia fluitans complex. The Bryologist 67(2): 146-152.

Borovichev, E.A. \& V.A. Bakalin 2013. Mannia levigata (Marchantiophyta: Aytoniaceae) - first record outside of Japan in the Russian Far East. Polish Botanical Journal 58(1): 217-220.

Borovichev, E.A. \& V.A. Bakalin 2014a. The survey of Marchantiales in the Russian Far East II. Wiesnerellaceae - a new family for the Russian liverworts flora. Arctoa 23: 1-4.

Borovichev, E.A. \& V.A. Bakalin 2014b. The survey of Marchantiales from the Russian Far East III. Note on Marchantia paleacea Bertol. Arctoa 23:25-28.

Borovichev, E.A., Yu.S. Mamontov \& V.A. Bakalin 2014. Revision of the Russian Marchantiales. I. A review of the genus Plagiochasma Lehm. et Lindenb. (Aytoniaceae, Hepaticae). Botanica Pacifica 3(2):19-26.

Borovichev, E.A., V.A. Bakalin \& A.A. Vilnet 2015. Revision of the Russian Marchantiales. II. A review of the genus Asterella P. Beauv. (Aytoniaceae, Hepaticae). Arctoa 24(2):294-313.

Borovichev, E.A., N. Kalinauskaite \& N.A. Konstantinova 2009. On the distribution of Conocephalum conicum and C. salebrosum (Marchanthiophyta) in Russia. Arctoa 18: 115-120.

Borovichev, E.A., N.A. Konstantinova \& E.N. Andrejeva 2012. The genus Sauteria Nees (Cleveaceae, Marchantiophyta) in Russia. Arctoa 20:181-188.

Borovichev, E.A., Yu.S. Kokoshnikova \& Yu.S. Mamontov 2011. New liverwort records from Vladimir province. 2. Arctoa 20:253.

Borovichev, E.A. \& A.A. Schestakova 2011. New liverwort records from Nizhniy Novgorod Province. 1. Arctoa 20:252.

Cherdantseva, V.Ya. \& S.K. Gambaryan 1989. Bryophytes. In: Griby, lishajniki i mohoobraznie Komsomol'skogog rapovednica. Dalnauka, Vladivostok, pp. 110-135 (in Russian). [Черданцева В.Я., Гамбарян С.К. Мохообразные // Грибы, Аишайники и мохообразные Комсомо ььского заповедника. Аальнаука, Владивосток. С. 110-135].

Damsholt, K. 2002. Illustrated Flora of Nordic Liverworts and Hornworts. Nordic Bryological Society, Lund, 840 pp.

Damsholt, K. 2013. The liverworts of Greenland. Nordic Bryological Society, Lund, $626 \mathrm{pp}$.

Ellis, L.T., S.A. Darzikolaei, S. Shirzadian, V.A. Bakalin, H. Bednarek-Ochyra, R. Ochyra, D. Claro et al. 2011. New national and regional bryophyte records, 29. Journal of Bryology 33(4):316-323.

Ellis, L.T., M. Alataş, A.K. Asthana, K.K. Rawat, V. Sahu, A. Srivastava, V.A. Bakalin et al. 2016. New national and regional bryophyte records, 47. Journal of Bryology 33 (online) DOI:10.1080/03736687.2016.1171453

Furuki, T. 2000. Riccia lamellosa Raddi newly found in Japan. Bryological Research 7(10):314-316.

Furuki, T. 2006. Riccia cavernosa Hoffm. newly found in Japan. Bryological Research 9(2):47-49.

Gambaryan, S.K. 1992. Anthocerotae and Hepaticae of southern Primorye. Dalnauka, Vladivostok, 175 pp. (in Russian). [Гамб̆арян С.К. 1992. Антоцеротовые и печеночники Южного Приморья. ВАаАивосток: Аальнаука. 175 с.].

Gambaryan, S.K. 2000. Additions to the hepatic flora. In: Rasteniya mussonnogo klimata, 48-49. Dal'nauka, Vladivostok (in Russian). [Гамбарян С.К. 2000. Аополнения к фморе печеночников. // Растения муссонного кАимата. ВАадивосток: Аальнаука, 48-49].

Gambaryan, S.K. 2001. Liverworts of the Sikhote-Alin Re- 
serve (Primorsky Territory). Arctoa 10:31-42 (in Russian). [Гамбарян С.К. Печеночники Сихотэ-Алинского заповедника (Приморский край). // Arctoa. T. 10, C. 31-42].

Hässel de Menéndez, G. 1963. Estudio de las Anthocerotales y Marchantiales de la Argentina. Opera Lilloana 7:1-297.

Higuchi, M. 2011. Endemic species of bryophytes in Japan. Bulletin of the National Museum of Nature and Science. Ser. B 37(3):117-126.

Horikawa, Y. 1934. Monographia hepaticarum AustraliJaponicarum. Journal of Science of the Hiroshima University. Series B. Division 2. Botany 2: 102-316.

Horikawa, Y. 1935. Symbolae Florae Bryophytae OrientaliAsiae I. The Botanical Magazine, Tokyo 48:452-462.

Jovet-Ast, S. 1964. Riccia crystallina L. emend. Raddi et Riccia cavernosa Hoffm., emend. Raddi (Note Preliminaire). Revue bryologique et lichénologique 33:459-483.

Jovet-Ast, S. 1978. Riccia des Îles Galapagos. Revue bryologique et lichénologique 44:411-428.

Jovet-Ast, S. \& H. Bischler 1966. Les Hépatiques d’Israël: Enumeration, notes écologiques et biogéographiques. Revue bryologique et lichénologique 34:91-126.

Katagiri, T. \& T. Furuki 2012. Checklist of Japanese liverworts and hornworts. Bryological Research 10(7):193-210.

Kiremit, H.O. \& M. Kirmaci 2012. Notes on Riccia fluitans and Riccia lamellosa (Ricciaceae, Hepaticae) in Turkey. Biological Diversity and Conservation (5)2:81-84.

Kıremit, H.O., M. Kirmaci \& F. Kıremit 2016. New findings of Riccia species (Marchantiophyta) in Turkey and Southwest Asia. Cryptogamie, Bryologie 37(1):19-25.

Kitagawa, N. 1965. Hepaticae of Sakhalin. Acta phytotaxonomica et geobotanica 19(4-6):146-152.

Konstantinova, N.A. 2000. Distribution patterns of the North Holarctic hepatics. Arctoa 9:29-94 (in Russian). [Константинова Н.А. 2000. Анализ ареалов печеночников Севера Голарктики. // Arctoa. Т. 9, С. 29-94].

Konstantinova, N.A., V.A. Bakalin, A.D. Potemkin \& M.S. Ignatov 2002. Hepatic flora of the Upper Burea River (Russian Far East). Arctoa 11:393-398.

Konstantinova, N.A., V.A. Bakalin, E.N. Andrejeva, A.G. Bezgodov, E.A. Borovichev, M.V. Dulin \& Yu.S. Mamontov 2009. Check-list of liverworts (Marchantiophyta) of Russia. Arctoa 18:1-63.

Kozhevnikov, A.E. 2007 Endemic element in the Russian Far East flora. V.L. Komarov Memorial Lectures 54: 8-81 (in Russian). [Кожевников A.Е. 2007. Эндемичный элемент во флоре российского Аальнего Востока. Комаровские чтения. 54:1-81].

Ladyzhenskaja, K.I. 1952. Riccia frostii Aust. in hepatics flora of USSR. Botanicheskie Mataterialy Otdela Sporovykh Rastenii 8: 180-188 (in Russian). [Аадыженская К.И. Riccia frostii Aust. во флоре печеночников СССР // Ботанические материалы отдела споровых растений. Т. 8. С. 180-188].

Ladyzhenskaja, K.I. 1961. Riccia lamellosa Radi and R. papillosa Moris. - new species for USSR liverwort flora. Botanicheskie Mataterialy Otdela Sporovykh Rastenii 14:252-262 (in Russian). [Аадыженская К.И. Riccia lamellosa Radi и R. papillosa Moris. - новые виды для флоры СССР // Ботанические материалы отдела споровых растений. Т. 14. C. 252-262].

Lindberg, S.O. 1872. Contributio ad floram cryptogamam Asiae boreali-orientalis. Acta Societatis Scientiarum Fennicae 10: 223-280.

Mamontov, Yu.S. 2007. Addition to the bryophyte flora of the Omsk Province. Vestnik Tomskogo Gosudarstvennogo Universiteta 305: 122-126 (in Russian). [Мамонтов Ю.C. 2007. Аополнения к флоре моховидных Омской обмасти // Вестник Томского государственного университета. Т. 305. С. 122-126].

Müller, K. 1952. Die Lebermoose Europas. In: Rabenhorst's Kryptogamenflora von Deutschland, Österreich und der Schweiz 6(3): 321-480.

Na-Thalang, O. 1980. A revision of the genus Riccia (Hepaticae) in Australia. Brunonia 3:61-140.

Paton, J.A. 1999. The liverwort flora of the British Isles. Harley Books, Colchester, 626 pp.

Perold, S.M. 1991. Taxonomic revision of the Ricciaceae Reichenb. (Marchantiales: Hepaticae) in southern Africa. $\mathrm{PhD}$ thesis. University of Pretoria. http:// repository.up.ac.za/dspa$\mathrm{ce} /$ handle $/ 2263 / 23897$ ?show $=$ full

Perold, S.M. 1999. Flora of southern Africa. Hepatophyta. Part I: Marchantiopsida. Fascicle I: Marchantiidae. National Botanical Institute, Pretoria, 249 pp.

Piippo, S. 1990. Annotated catalogue of Chinese Hepaticae and Anthocerotae. Journal of Hattori Botanical Laboratory 68:1-192.

Potemkin, A.D. 2003. New and little known for Russia hepatics from Kamchatka and Primorskiy Territory (Russian Far East). Arctoa 12:75-82 (in Russian). [Потемкин А.А. 2003. Новые и малоизвестные Аля России печеночники с Камчатки и из Приморского края (российский Аальний Восток) // Arctoa T. 12. С. 75-82].

Potemkin, A.D. 2011. New liverwort records from Novgorod Province. 1. Arctoa 20:248.

Potemkin, A.D. \& E.Z. Baisheva 2010. New liverwort records from Bashkortostan Republic. 2. Arctoa 19:259-260.

Potemkin, A.D. \& V.M. Kotkova 2008. New liverwort records from Republic of Karelia. Arctoa 17:191-192.

Potemkin, A.D., V.M. Kotkova \& E.V. Kushnevskaya 2008. New liverwort records from Leningrad Province. Arctoa 17:194-195.

Potemkin, A.D. \& A.A. Notov 2010. New liverwort records from Tver Province. 1. Arctoa 19:265-267.

Potemkin, A.D. \& A.D. Volobaev 2008. New liverwort records from Republic of Khakassia. Arctoa 17:216 (in Russian). [Потемкин А.А., Волобаев П.А. 2008. Новые находки печеночников в респубиике Хакассия // Arctoa. T. 17. C. 216]

Schiffner, V. 1899. Ueber einige Hepaticae aus Japan. Österreichische botanische Zeitschrift 49:385-395.

Schljakov, R.N. 1982. The Hepatics of the North of the USSR. Vol. 5. Leningrad, Nauka, 196 pp. (in Russian). [Шیяков Р.Н. 1982. Печеночные мхи Севера СССР. Аенинград: Наука. Т. 5. 196 с.]

Scott, G.A.M. 1985. Southern Australian Liverworts. Commonwealth of Australia, Canberra. 1-216.

Shimizu, D. \& S. Hattori 1953. Marchantiales of Japan, I. Journal of Hattori Botanical Laboratory 9:32-44.

Schuster, R.M. 1992. The Hepaticae and Anthocerotae of North America east of the hundredth meridian. Vol. 6. Chicago, Field Museum. 937 pp.

Schumacker, R. \& J. Váňa 2005. Identification keys to the liverworts and hornworts of Europe and Macaronesia (distribution and status). 2-nd edition fully revised and updated. Sorus, Poznan. 211 pp.

Söderström, L., E. Urmi, J. Váňa 2002. Distribution of Hepaticae and Anthocerotae in Europe and Macaronesia. Lindbergia 27: 3-47.

Söderström, L., A. Hagborg, M. von Konrat, S. Bartholo- 
mew-Began, D. Bell, L. Briscoe, E. Brown et al. 2016. World checklist of hornworts and liverworts. PhytoKeys 59:1-828.

Sofronova, E.V. 2007. The Hepaticae of the Natural park "Lenskye Stolby" (Middle Lena River, Central Yakutia) Novosti Sistematiki Nizshikh Rastenii 41:335-341 (in Russian). [Софронова Е.B. 2007. Печеночники природного парка «Аенские столбы» (среднее течение р. Аены, Центральная Якутия) // Новости систематики низших растений. Т. 41. С. 335-341].

Stotler, R. \& W.T. Doyle 2004. Riccia crystallina verified in North America, North of Mexico. The Bryologist 107(1): 107-110.

Taran, G.S., V.A. Bakalin 2008. New record of Riccia beyrichiana Hampe (Hepaticae) in Siberia. Bulleten' Moskovskogo obshchestva ispytatelei pryrody. Otd. biol. 113(3):85 (in Russian). [Таран Г.С., Бакалин B.A. 2008. Новая находка Riccia beyrichiana Hampe (Hepaticae) в Сибири // Бюлметень Московского общества испытателей природы. ОтА.
Биол. Т. 113, №3. С. 85].

Taran, G.S., S.G. Kazanovskiy \& E.Ya. Muldiyarov 2006. Bryoflora of Vakh-Tym section of the Ob river floodplain in space of plant communities. In: Biologicheskie resursy i prirodopol'zovanie 9, pp. 80-108 (in Russian). [Таран Г.C., Казановский С.Г., Мульдияров Е.Я. 2006. Бриофлора Вах-Тымского отрезка Оби в пространстве растительных сообществ // Биологические ресурсы и природопользование. Вып. 9. Сургут. С. 80-108].

Tominaga, T. \& T. Furuki 2014. Taxonomic studies of the genus Riccia sect. Riccia (Ricciaceae, Hepatics) in Japan. Bryological Research 11(3):53-62.

Vianna, E.C. 1981. Marchantiales. Boletim, Instituto Central de Biociências, Universidade Federal do Rio Grande do Sul 38: 1-213.

Yamada, K. \& Z. Iwatsuki 2006. Catalog of the hepatics of Japan. Journal of Hattori Botanical Laboratory 99: 1-106. 